\title{
The Trust in Indicators: Measuring Human Rights
}

\author{
AnnJanette Rosga* \\ Margaret L. Satterthwaite**
}

I. Introduction

II. Indicating Lack of Trust: The Evolving Approach to Human Rights

Indicators.

A. The Overdue Emphasis on Economic, Social and Cultural Rights.... 259

B. The Quest to Hold States Accountable: How to Identify an Individual's Rights and Determine When a State Has Fulfilled its Obligations.....

C. Measuring Implementation: "Available Resources," Immediate Obligations, and Indications of Progress

D. Indeterminacy, Indicators, and the Turn Toward Monitoring of Monitoring

III. Audit, Distance, and the Problem with Trusting Indicators

A. Indicators as Audit Practice

* United Nations Office Director, Women's International League for Peace and Freedom. Gender \& Security Sector Reform Consultant. Ph.D., History of Consciousness (Cultural Anthropology), University of California, Santa Cruz, 1998.

** Faculty Director, Center for Human Rights and Global Justice, New York University School of Law and Associate Professor of Clinical Law. J.D., NYU School of Law, 1999, M.A., University of California at Santa Cruz, 1995. Work on this Article was supported by the Filomen D'Agostino Research Fund at New York University School of Law. The authors wish to thank the following individuals for discussions of indicators and/or their comments on early drafts of this Article: Philip Alston, Yulia Krieger, Alice M. Miller, Madeleine Rees, Annelise Riles, Mindy Roseman, Sara Steen, Lee Waldorf, and Jill Williams. They are grateful to more recent readers for insightful comments: Eyal Benvenisti, Nehal Bhuta, Amanda Conley, Kevin Davis, Jason Eyster, Benedict Kingsbury, Minna Kotkin, Sally Engle Merry, Binny Miller, Alison Nathan, Sarah Paoletti, Richard Stewart, and Erica Thorson as well as the participants in the Fall 2008 NYU Hauser Colloquium on Globalization and its Discontents, where a draft of this paper was presented. The authors are grateful to Samantha Rowe (NYU LL.M. '08) for outstanding research assistance and indepth suggestions, Ryan Gee (NYU J.D. expected '10) and Shannon Kunath (NYU J.D. expected '09) for research assistance, and the editors of the Berkeley Journal of International Law. Remaining errors are solely the responsibility of the authors. A prior version of this paper was published online by New York University School of Law as the Center for Human Rights and Global Justice Working Paper No. 20, 2008. 
B. The Problems with Trusting Indicators

C. Goodhart's Law: The Tendency for Measures to Become Targets.... 285

IV. Enter the Experts: Renewed Efforts to Create International Human

Rights Indicators

A. The Troubled Authority of the Human Rights Treaty Bodies in

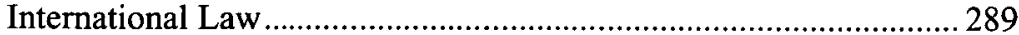

B. Expert Indicators: The OHCHR Indicators Initiative .............................. 293

V. Human Rights Indicators as Technologies of Global Governance.............. 304

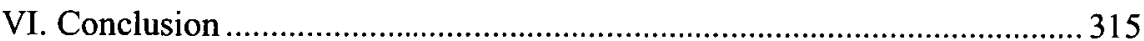

Debates over the best way to identify human rights violations, assess compliance with treaty obligations, and measure human rights progress over time have preoccupied scholars and practitioners for many years. These debates have been especially pressing in the field of economic, social, and cultural rights, where the need for new methodologies has been felt most urgently. Quantitative data has been forwarded as a central tool in the drive for better methods of assessment, monitoring, and advocacy. Among quantitative tools, human rights indicators have been identified as especially powerful. Rights indicators, "piece[s] of information used in measuring the extent to which a legal right is being fulfilled or enjoyed in a given situation," 2 are understood to

1. This title is adapted from THEODORE M. PORTER, Trust In Numbers: THE PURSUIT OF OBJeCtivity IN SCIENCE AND PUBLIC LIFE (1995). Each of the authors has been, in various capacities, involved in projects to help develop and/or analyze such indicators. As a cultural anthropologist (Rosga) and human rights legal scholar (Satterthwaite) respectively, we drafted this Article as a way of thinking through the interdisciplinary functions of human rights indicators, as they seemed to embody an especially powerful intersection of law and social science. Rosga spent 2002 in Bosnia-Herzegovina conducting ethnographic fieldwork on democratic police reform initiatives. While in residence, she also provided consultation to the U.N. Office of the High Commissioner for Human Rights (OHCHR) on human rights indicators for use in a nationwide "Municipal Assessment Project" and to UNICEF on social science methodologies relevant to the assessment of the nature and extent of child trafficking. More recently, she facilitated a meeting for OHCHR on the development of indicators for monitoring/assessing human trafficking in Europe. Satterthwaite served as a consultant to the Human Rights Section of UNIFEM during 2002-2003, where she helped to develop a methodology and set of CEDAW indicators for use in Central and Eastern Europe. She was also an invited expert at the December 2006 Experts Meeting on Human Rights Indicators hosted by the U.N. Office of the High Commissioner for Human Rights in Geneva.

2. Maria Green, What We Talk About When We Talk About Indicators: Current Approaches to Human Rights Measurement, 23 HUM. RTS. Q. 1062, 1065 (2001). Paul Hunt, former U.N. Special Rapporteur on the Right to Health, has offered the following definition: "...a human rights indicator derives from, reflects and is designed to monitor realization or otherwise of a specific human rights norm, usually with a view to holding a duty-bearer to account." Paul Hunt, WHO Workshop on Indicators for the Right to Health, A Background Note (2003), available at http://www.jus.uio.no/forskning/gnupper/humrdev/indicators.html. 
have a variety of advantages: they render complex data simple and easy to understand; they can be designed to demonstrate compliance with obligations, fulfillment of rights, and government efforts toward these goals; and they are capable of capturing progress over time and across countries. ${ }^{3}$ Since they are perceived to be an especially powerful intersection of law and social science, it is not surprising that NGOs, inter-governmental bodies, and governments have all begun to develop human rights indicators. ${ }^{4}$ Indeed, it is fair to say that there is an emerging market in human rights indicators.

As an especially powerful intersection of law and social science, human rights indicators require the identification, creation, collection, analysis, and dissemination of quantitative data. They are used to accomplish many, often contradictory, ends. They take their place among many manifestations of what scholars have identified as an exponential growth of global governance projects. ${ }^{5}$ As such, they are situated at the nexus of international human rights law, demographic and other quantitative social science methodologies, multiple administrative and regulatory apparatuses, global, regional and local advocacy projects, and the transnational spread of technocracies and expert knowledges mobilized in the service of "standardization."

3. For a discussion of the advantages of human rights indicators for treaty bodies, States, and advocacy organizations, see Judith V. Welling, International Indicators and Economic, Social, and Cultural Rights, 30 HUM. RTS. Q. 933, 940-47 (2008).

4. In the last several years, a wide variety of international organizations, including the U.N. Development Fund for Women (UNIFEM), the United Nations Children's Fund (UNICEF), as well as the Office of the High Commissioner for Human Rights and several U.N. Special Rapporteurs, have undertaken human rights indicators projects. At the regional level, the Inter-American Commission on Human Rights has developed guidelines for the use of indicators in monitoring economic and social rights. International NGOs including the Centre on Housing Rights and Evictions (COHRE) and the American Association for the Advancement of Science (AAAS) have embarked on the creation of their own human rights indicators. Finally, national and regional human rights institutions such as the Danish Institute for Human Rights, the German Institute for Human Rights, and the Inter-American Commission on Human Rights have begun work on human rights indicators. For a discussion of numerous human rights indicators initiatives, see Rajeev Malhotra \& Nicolas Fasel, Quantitative Human Rights Indicators: A Survey of Major Initiatives (Mar. 3, 2005) (unpublished draft), available at http://www.jus.uio.no/forskning/grupper/humrdev/indicators.html. See also Welling, supra note 3 at 936-40 (discussing recent initiatives to create international human rights compliance indicators).

5. See Sally Engle Merry, Measuring the World: Indicators, Human Rights, and Global Governance (July 17, 2008) (unpublished manuscript, on file with authors). For a discussion of global governmentality, see, for example, James Ferguson \& Akhil Gupta, Spatializing States: Toward an Ethnography of Neoliberal Governmentality, 29 AM. ETHNOL. 981 (2002); David Kennedy, Challenging Expert Rule: The Politics of Global Governance, 27 SYDNEY L. REv. 5 (2005); Tania Murray Li, Beyond "the State" and Failed Schemes, 107 AM. ANTHROPOL. 383 (2005); Nikolas Rose \& Peter Miller, Political Power Beyond the State: Problematics of Government, 43 BRIT. J. SOC. 173 (1992).

6. See, e.g., Winton Higgins \& Kristina Tamm Hallström, Standardization, Globalization, and Rationalities of Government, 14 ORGANIZATION 685 (2007); Suzan Ilcan \& Lynne Phillips, Making Food Count: Expert Knowledge and Global Technologies of Government, 40 CAN. REV. SOC. \& ANTHROPOL. 441 (2003). 
As early as the 1980 s, assessments of the role of statistics in measuring human rights contained variously embedded discussions of indicators, including critical assessments of their use. ${ }^{7}$ In spite of early warnings about problems with indicators, ${ }^{8}$ a convergence of social, political, and economic forces and their accompanying epistemological shifts has, if anything, dramatically increased the power of indicators without accompanying attention to their limitations. This power fuels the growing demand for indicators that has arisen from the perceived need within international human rights circles for better tools to hold governments to account for their human rights obligations and from the replication of verification and monitoring techniques used in a wide variety of business, non-profit, and governmental management contexts. ${ }^{9}$ In 1994, economic analyst Michael Power identified what he called an "audit explosion," which he described as having "roots in a programmatic restructuring of organizational life and a new "rationality of governance." 10 For Power, the audit, with its financial accounting origins, exemplifies both literally and metaphorically a number of monitoring and control practices characteristic of late modern social organization such as inspections, assessments, and other evaluative technologies.

Audit has become a benchmark for securing the legitimacy of organizational action in which auditable standards of performance have been created not merely to provide for substantive internal improvements to the quality of service but to make these improvements externally verifiable via acts of certification. ${ }^{11}$

Increasing demands for "indicators" are thus inextricable from the privileging of abstract, quantifiable, and putatively transferable data bits. As such, indicators partake of both the strengths and weaknesses of auditing practices. This Article is our effort to distill some of those strengths and weaknesses, through a careful examination of the turn toward indicators in the human rights context, a consideration of insights from science studies scholars, and an assessment of the current state of play. Without arguing whether indicators are inherently good or bad, we suggest that those caught up in the rush to create and apply indicators within the field of human rights would do well to recognize the ways in which the demand for indicators is inextricable from a widespread turn to "accounting culture" in which tests of measurability often prevail over accurate and contextually sensitive assessments of substance or actions.

Human rights indicators are being deployed to achieve three predominant goals:

7. See infra Section II for a partial account of this history.

8. See especially Russel Barsh, Measuring Human Rights: Problems of Methodology and Purpose, 15 HUM. RTS. Q. 87 (1993).

9. Id. at 90-92.

10. Michael Power, The Audit Society: Rituals of Verification 10 (1997) (quoting Rose \& Miller, supra note 5).

11. Id. at 10-11. 
1. To monitor compliance with, and fulfillment ${ }^{12}$ of, human rights commitments. ${ }^{13}$

2. To measure the progress of human development in human rights terms. For instance, the Office of the High Commissioner for Human Rights has developed "a list of simple development indicators, designed to measure 'what is', on a right-by-right basis." 14

3. To measure the impact/success of particular rights-based development programming. Many U.N. agencies, for example, have begun to use socioeconomic data disaggregated to highlight gender, race, and other axes of discrimination to measure the impact of their programming on specific beneficiary populations. ${ }^{15}$

This Article restricts its analysis to the first of these categories-what we will call compliance indicators. However, it is likely that a number of points apply across all three categories.

This Article closely examines the use of indicators by U.N. bodies charged with monitoring State compliance with human rights treaties, including the treaty bodies and the U.N. Office of the High Commissioner for Human Rights. The focus is on these actors because, in the now booming market of indicators projects, these bodies retain a privileged position under international law. The U.N. treaty bodies-created and vested with specified powers by the States that have ratified the relevant treaties - have a special, legally-defined relationship to States: they are authorized to review and assess State compliance with human rights treaties. ${ }^{16}$ Because of these legally-defined relationships, an examination

12. Sakiko Fukuda-Parr, Terra Lawson-Remer, and Susan Randolph propose a new Index of Economic and Social Rights Fulfillment that "evaluates and compares countries on their fulfillment of Economic and Social Rights obligations." While the index is based on State obligations to respect, protect, and fulfill human rights obligations, it is not aimed at assessing compliance as a legal matter, thus distinguishing it from the indicators projects discussed in this Article. See Sakiko Fukuda-Parr, Terra Lawson-Remer \& Susan Randolph, Measuring the Progressive Realization of Human Rights Obligations: An Index of Economic and Social Rights Fulfillment 1 (U Conn., Econ. Rights Working Papers, Paper No, 8, 2008).

13. See, e.g., Green, supra note 2 .

14. Craig G. Mokhiber, Toward a Measure of Dignity: Indicators for Rights-Based Development, 18 STAT. J. U.N. ECON. COMM'N FOR EUR. 155, 157 n.18 (2001). For a discussion of the differences between human rights indicators and rights-based development indicators, see U.N. Dev. Program [UNDP], Using Indicators for Human Rights Accountability, in HUMAN DEVElopment RePORT 2000: Human RightS AND Human DEVElopMENT 89 (2000). See also Welling, supra note 3, at 949.

15. UNICEF, for example, had begun to use such indicators as net school enrollment ratios disaggregated by gender and dropout rates by grade, gender and age, to measure the impact of their programming to improve girls' education in various countries. See UNICEF, Girls' Education: $A$ Framework for Action 7 (2000).

16. Further, while non-State actors such as corporations have broad-ranging impacts on human rights and may be seen to assume certain human rights obligations, the State remains the primary 
of how the treaty bodies-assisted by an expert institution charged with supporting the treaty bodies, the U.N. Office of the High Commissioner for Human Rights-have begun to use indicators in their monitoring of State compliance, brings certain crucial issues into focus. Specifically, a close examination of the work of these U.N. bodies demonstrates that they are attempting to use human rights indicators to hold States to account in a context where their authority is constantly challenged by national governments.

This Article places these efforts to create human rights indicators in conversation with scholarship on audit and standardization from the social sciences. We conclude that while there are very real drawbacks involved in the indicators project, debates about indicators may provide advocates with new opportunities to use the language of science and objectivity as a powerful tool to hold governments to account. However, because human rights compliance indicators threaten to close space for democratic accountability and purport to turn an exercise of judgment into one of technical measurement, advocates of human rights should to remain vigilant to effects of the elisions at work in the indicators project. The conundrum of democratic accountability and the failure to clearly locate responsibility for judgment in international human rights assessment exercises are not products of the tools chosen to carry out those exercises, but are instead structural problems, foundational to international human rights law as it exists today. Thus, some of the core problems we argue are inherent in the indicators project would still be present even if quantitative indicators were banished from human rights assessment projects. Nonetheless, the use of quantitative indicators tends to disguise those problems as technical ones of measurement and data availability.

The Article unfolds as follows: in Section II, we explore some of the conditions leading to the increasing reliance on indicators for monitoring the fulfillment and/or enjoyment of international human rights, especially economic and social rights. Using the example of the International Covenant on Economic, Social and Cultural Rights (ICESCR), we consider the way in which that treaty's monitoring committee has shifted from attempting to create and directly apply indicators in the measurement of compliance with treaty obligations to calling on States to identify and implement their own indicators. In Section III, we discuss several of the problems integral to the use of indicators in human rights contexts and what those difficulties have in common with the wider turn to auditing practices in management and control contexts. In Section IV, we examine the ongoing efforts of the human rights treaty bodies and the U.N. Office of the High Commissioner for Human Rights to create international indicators applicable to all States, and we assess that effort in light of the problems discussed in Section III, as well as considering issues of authority and judgment in human rights law. Section V considers human rights

guarantor and thus directly accountable under international human rights law. This Article therefore focuses on indicators projects aimed at holding States to account. 
indicators as a technology of global governance, warning that-if not carefully designed to do otherwise-human rights compliance indicators have a tendency to close off spaces for participation and democratic contestation.

II.

INDICATING LACK OF TRUST: THE EVOLVING APPROACH TO HUMAN RIGHTS INDICATORS

The crucial point is that faith in the objectivity of quantitative methods is not quite the same thing as acceptance of the validity of their conclusions. The "objectivity" of quantitative policy studies has more to do with their fairness and impartiality than with their truth.

Theodore M. Porter ${ }^{17}$

A sense of the history surrounding the use of compliance indicators in the human rights context may be helpful. This Section will consider some of that history, examining the overdue emphasis on economic, social and cultural rights; the quest to hold States accountable for a set of rights that at first appeared indeterminate; and the ultimate articulation of the role of international scrutiny as one of assessing the State's own monitoring. In requesting States Parties to create their own indicators and assigning itself the task of reviewing these indicators, the U.N. Committee on Economic, Social and Cultural Rights (CESCR) relies upon well-trod assumptions about how to ensure impartiality in conditions of mutual mistrust. We will suggest that this turn to monitoring of monitoring, or "control of control," replaces-at least in part-the Committee's task of assessing the fulfillment or enjoyment of substantive rights with an auditing role.

\section{A. The Overdue Emphasis on Economic, Social and Cultural Rights}

It is almost a cliché now to say that economic, social and cultural rights (ESC rights) were ignored by the international community, and by the human rights world, for too long. But in 1993, when the international community gathered for the World Conference on Human Rights in Vienna, the point still had to be made forcefully. In a speech to the World Conference, a spokesperson for the CESCR summarized the situation this way:

The shocking reality ... is that States and the international community as a whole continue to tolerate all too often breaches of economic, social and cultural rights which, if they occurred in relation to civil and political rights, would provoke expressions of horror and outrage and would lead to concerted calls for immediate remedial action....

17. Theodore M. Porter, Objectivity as Standardization: The Rhetoric of Impersonality in Measurement, Statistics, and Cost-Benefit Analysis, in RETHINKING OBJECTIVITY 197, 207 (Allan Megill ed., 1994). 
The fact that one fifth of the world's population is afflicted by poverty, hunger, disease, illiteracy and insecurity is sufficient grounds for concluding that the economic, social and cultural rights of those persons are being denied on a massive scale. Yet there continue to be staunch human rights proponentsindividuals, groups, and Governments-who completely exclude these phenomena from their concerns. ${ }^{18}$

The response to this kind of critique-the adoption in Vienna of language in the Declaration and Programme of Action that explicitly recognized and emphasized the universality, indivisibility and interdependence of all human rights - should not have been revolutionary. ${ }^{19}$ Indeed, from the inception of the modern human rights system (about the time of the adoption of the Universal Declaration of Human Rights (UDHR) in $1948,{ }^{20}$ to take an unsatisfactory but not altogether arbitrary moment), ESC rights lived alongside civil and political rights. ${ }^{21}$ The UDHR includes both types of rights, and the U.N. system could have developed equally robust treaties, monitoring systems, and assistance in implementation for the two categories. Instead, the idea of human rights was held captive to the Cold War and to colonial, and then postcolonial, factionalism. $^{22}$ Two treaties instead of one were created to implement the $\mathrm{UDHR}^{23}$; the international community took civil and political rights far more

18. U.N. Comm. on Econ. Soc. \& Cultural Rts. [CESCR], Statement to the World Conference on Human Rights on Behalf of the Committee on Economic, Social and Cultural Rights, ๆף 5, 8, Annex No. IIJ, U.N. Doc. E/1993/22 (1993).

19. Article 5 of the Declaration and Programme of Action reads: "All human rights are universal, indivisible and interdependent and interrelated. The international community must treat human rights globally in a fair and equal manner, on the same footing, and with the same emphasis." World Conference on Human Rights, June 14-25, 1993, Vienna Declaration and Programme of Action, I I(5), U.N. Doc. A/CONF.157/23 (July 12, 1993) [hereinafter Vienna Declaration].

20. Universal Declaration of Human Rights, G.A. Res. 217A, U.N. GAOR, 3d Sess., 1st plen. mtg. at 71, U.N. Doc. A/810 (Dec. 12, 1948), reprinted in 43 AM. J. INT'L L. 127 (Supp. 1949).

21. See articles 3 and 4 (the right to life, liberty and the security of person, and the right to be free of slavery) and articles 22 and 25 (the right to social security, and the right to an adequate standard of living) for examples.

22. For a discussion of these issues, see HENRY J. STEINER, PHILIP ALsTON \& RYAN GoOdman, InTERnational Human Rights in CONTEXT: LaW, Politics, MORALS 263-80 (3d ed. 2008). See also MATTHEW CRAVEN, THE INTERNATIONAL COVENANT ON ECONOMIC, SOCIAL AND CULTURAL Rights: A PERSPECTIVE ON ITS DEVELOPMENT 7-16 (1995).

23. These are, of course, the International Covenant on Economic, Social and Cultural Rights, adopted Dec. 16, 1966, 993 U.N.T.S. 3 [hereinafter ICESCR] (entered into force Jan. 3, 1976), and the International Covenant on Civil and Political Rights, adopted Dec. 16, 1966, 999 U.N.T.S. 171 [hereinafter ICCPR] (entered into force Mar. 23, 1976). The creation of two treaties-one concerning civil and political rights, and one on ESC rights - was a product of politics much more than an outgrowth of any specific understanding of human rights. Indeed, as Craig Scott notes, the UDHR had seamlessly included both categories of rights. See Craig Scott, Reaching Beyond (Without Abandoning) the Category of "Economic, Social and Cultural Rights," 21 HUM. RTS. Q. 633, 633 (1999) ("One of the dominant normative features of the Universal Declaration of Human Rights (UDHR) is the relatively integrated translation of the aspiration to protect human dignity into the enumeration of fundamental human rights. The bifurcation of what is now thought of as the two grand categories of human rights (so-called 'civil and political rights' and 'economic and social rights') had yet to occur at the time of the UDHR's adoption. These categories were progeny of the 
seriously on the whole than ESC rights ${ }^{24}$; and theoretical arguments about the nature of the different categories, and the priority that should be accorded to each, proliferated. ${ }^{25}$ On the whole, ESC rights suffered a long-term marginalization, characterized by the late creation of a treaty-monitoring body for the ICESCR, ${ }^{26}$ general assumptions that ESC rights were either nonjusticiable or merely aspirational or both, ${ }^{27}$ and by a lack of infrastructure for their advancement in the form of NGOs, professional experts, and legal norms. ${ }^{28}$ In this context, the Vienna Declaration's assertion of the indivisibility, universality, and interdependence of all human rights brought the struggle for ESC rights one large step forward. ${ }^{29}$

Of course, in many ways, that giant step embodied a recognition of some developments that had already taken place. The CESCR, established in the mid1980 s, had developed strong, professional working methods by 1993 , including the adoption of concluding observations ${ }^{30}$ and the promulgation of a number of substantively rigorous General Comments. ${ }^{31}$ A group of eminent scholars and

UDHR, later created through two instruments: the International Covenant on Civil and Political Rights (ICCPR) and the International Covenant on Economic, Social and Cultural Rights (ICESCR).") (citations omitted).

24. For a discussion of these issues, see STEINER, ALSTON \& GOODMAN, supra note 22. See also Rhoda Howard, The Full-Belly Thesis: Should Economic Rights Take Priority over Civil and Political Rights? Evidence from Sub-Saharan Africa, 5 HUM. RTS. Q. 467 (1987).

25. For a discussion of these issues, see STEINER, ALSTON \& GOODMAN, supra note 22.

26. Unlike the other major human rights treaties, the ICESCR did not include provision for a treaty monitoring body. As the U.N. Office of the High Commissioner for Human Rights explains, "Unlike the five other human rights treaty bodies, the [U.N.] Committee on Economic, Social and Cultural Rights was not established by its corresponding instrument. Rather, the Economic and Social Council (ECOSOC) created the Committee, following the less than ideal performance of two previous bodies entrusted with monitoring the Covenant. The Committee was established in 1985 , met for the first time in 1987 and ... [now] convenes twice a year. ." OHCHR, Fact Sheet No.16 (Rev.1), The Committee on Economic, Social and Cultural Rights (July 1991), available at http://www.unhchr.ch/html/menu6/2/fs16.

27. See CRAVEN, supra note 22.

28. See Scott Leckie, Another Step Towards Indivisibility: Identifying the Key Features of Violations of Economic, Social and Cultural Rights, 20 HUM. RTS. Q. 81, 81-82 (1998) (noting that "[o]f all the domains where state and intergovernmental action on human rights have failed to achieve anything more than modest success, the development of effective measures for the prevention and remedying of violations of economic, social and cultural rights must surely classify as one of the most glaring. Although the international community has consistently reiterated the proposition that all human rights are intertwined within a coherent system of law, responses to violations of economic, social and cultural rights-both procedural and substantive-have paled in comparison to the seriousness accorded infringements of civil and political rights.").

29. Many others have emphasized that the rhetorical progress in the Vienna Declaration and Program of Action was not matched by substantive advances within the document or programmatic steps in the program of action. See Audrey R. Chapman, A "Violations Approach" to Monitoring the International Covenant on Economic, Social and Cultural Rights, 18 HUM. RTS. Q. 23, 25 n.3 (1996).

30. For a discussion of the development of the CESCR's concluding observations, see CRAVEN, supra note 22, at 87-89.

31. See, e.g., Office of the High Comm'r of Hum. Rts., CESCR General Comment No. 4, The 
practitioners had gathered in the Netherlands in 1987, developing the Limburg Principles, a framework for understanding the nature and scope of the obligations of States Parties to the ICESCR. ${ }^{32}$ And national judiciaries began to interpret and thereby give content to ESC rights included in domestic constitutions and legislation. ${ }^{33}$ This work was important because, taken together, it gave the lie to the idea that ESC rights were unwieldy, illegitimate, or lacking content. Still, these developments were largely ignored by the world's superpowers - and indeed, by various governments of all stripes-and much remained to be done. ${ }^{34}$

Since Vienna, some major advances have taken place. The U.N.'s human rights field offices, administered largely by the U.N. High Commissioner for Human Rights, have begun to promote and monitor ESC rights. ${ }^{35}$ The Limburg Principles were supplemented by the Maastricht Guidelines, which entail a conceptual framework for violations of ESC rights. ${ }^{36}$ And the ICESCR has moved to center stage, now recognized in the literature and in advocacy

Right to Adequate Housing, U.N. Doc. E/1992/23 (1991), reprinted in U.N. Secretariat, Compilation of General Comments and General Recommendations Adopted by Human Rights Treaty Bodies, 22, U.N. Doc. HRI/GEN/1/Rev.5 (Apr. 26, 2001); see also discussion infra note 135 and accompanying text.

32. The Limburg Principles were developed by a group of experts gathered at the University of Limburg in 1986 in an effort to define, under international law, the nature and scope of States Parties' obligations under the ICESCR. The Limburg Principles assert, among other important principles, that: some rights in the Covenant are immediately justiciable, while others become justiciable over time; States Parties have an immediate obligation to take steps toward fulfilling the rights under the Covenant; and progressive realization was not an excuse to deter indefinitely measures aimed at fulfilling Covenant rights. See U.N. Hum. Rts. Comm'n., Note Verbale dated 5 December 1986 from the Permanent Mission of the Netherlands to the United Nations Office at Geneva addressed to the Centre for Human Rights ("Limburg Principles"), Annex, U.N. Doc. E/CN.4/1987/17 (Jan. 8, 1987) (submitting the Limburg Principles on the Implementation of the Intemational Covenant on Social, Economic and Cultural Rights).

33. For a discussion of the ways in which courts have played a role in enabling litigation for ESC rights in specific contexts, see, for example, STEINER, ALSTON \& GOODMAN, supra note 22, at 313-58; and Mario Gomez, Social Economic Rights and Human Rights Commissions, 17 HUM. RTs. Q. 155, 155-57 (1995) (discussing ESC rights litigation under the Indian Constitution).

34. For a discussion of the "ambivalence" of the world's governments concerning ESC rights, see STEINER, ALSTON \& GOODMAN, supra note 22, at 263-64.

35. For example, the field office in Bosnia-Herzegovina has identified ESC rights as one of its priority areas for action. See OHCHR - Bosnia and Herzegovina, Human Rights Field Presence in Bosnia and Herzegovina, http://www.unhchr.ch/html/menu2/5/bosnia.htm (last visited Sept. 30, 2008).

36. The Maastricht Guidelines were developed ten years later in a similar fashion. Experts gathered at the renamed Maastricht University and adopted a set of principles that were aimed at "elaborat[ing] on the Limburg Principles as regards the nature and scope of violations of economic, social and cultural rights and appropriate responses and remedies." The Guidelines include sections addressing, inter alia: the obligations to respect, protect and fulfill; obligations of conduct and result; minimum core obligations; and availability of resources. Maastricht Guidelines on Violations of Economic, Social and Cultural Rights, Maastricht, January 22-26, 1997, wwwl.umn.edu/humanrts/ instree/Maastrichtguidelines.html. 
campaigns as equally important as the ICCPR. ${ }^{37}$ As practice scrambled to catch up with rhetoric, the human rights community began searching for appropriate tools and methodologies for the advancement of ESC rights.

There are a number of reasons why the tools and professional practices developed to monitor and implement civil and political rights have proved in some ways inadequate to the task of monitoring and implementing ESC rights. Several of those reasons will be examined briefly here, including: the different formulation of States' obligations and individuals' rights in the ESC context; the qualification of States' duties according to the availability of resources; and the fact that $\mathrm{ESC}$ rights have been perceived to be more indeterminate than civil and political rights.

\section{B. The Quest to Hold States Accountable: How to Identify an Individual's Rights and Determine When a State Has Fulfilled its Obligations}

Anyone reading the ICCPR and the ICESCR side by side will immediately notice a significant difference in the way the rights of individuals are described. Beyond the content of the rights themselves, the framing of the rights is quite different. For example, article 7 of the ICCPR declares that "[n]o one shall be subjected to torture or to cruel, inhuman or degrading treatment or punishment," while article 7 of the ICESCR reads "[t]he States Parties to the present Covenant recognize the right of everyone to the enjoyment of just and favourable conditions of work. .." The difference in phraseology is instantly apparent: on the one hand, "no one shall be subjected to" violations of their civil and political rights, and on the other hand "States Parties recognize" certain ESC rights. While this difference is striking, its significance is not inherently obvious. In the early years of attention to ESC rights, however, the "States Parties recognize" formula was characterized as "programmatic," or "aspirational," meaning that it did not directly create a right to which an individual could unproblematically cling. ${ }^{38}$ Instead, the phrase was seen as creating an

37. A review of the website of the Office of the U.N. High Commissioner for Human Rights demonstrates the extensive resources available to those working on both categories of rights. See Office of the High Commissioner for Human Rights / OHCHR Welcome Page, http://www.ohchr. org (last visited Sept. 30, 2008). In recent years, there has been a proliferation of NGOs in both the global North and the global South working on ESC rights. For a snapshot of some of these organizations, see ESCR-Net: Our Members, http://www.escr-net.org/members/members_ list.htm (last visited Sept. 30, 2008). ESCR-Net is itself a testament to the growth in this field: established over the last several years, it describes itself as follows: "The International Network for Economic, Social and Cultural Rights (ESCR-Net) is an emerging coalition of organizations and activists from around the world dedicated to advancing economic, social and cultural rights. This website contains four interactive, searchable databases (or directories) of organizations and individuals, projects and activities, regional and domestic case law, and events." The project is funded by the Ford Foundation and housed at the Center for Economic and Social Rights in Brooklyn, NY. Its inaugural conference was held in Thailand in June 2003.

38. See Leckie, supra note 28; and STEINER, ALSTON \& GOODMAN, supra note 22, for a discussion of this line of thought. 
obligation on States Parties to construct programs, to design policies, or to set up regulatory systems that would allow individuals to enjoy the full realization of their rights. Such programs and policies would demonstrate that the State "recognizes" the right. The enjoyment of the right was less important, it seemed, than the fact that means had been identified to effect that enjoyment.

Rights theorists tended to construct a dichotomy in which civil and political rights were perceived to be obligations of result, while ESC rights were understood to be qualitatively different: obligations of conduct. ${ }^{39}$ What kind of program would States need to set up to demonstrate that they "recognize" the right to just and favorable conditions of work, for example? Was there any check on effectiveness, or a way to make sure individuals actually benefited from such programs? To take the example of just and favorable working conditions, could an advocate conclude from the fact that an individual worker was unable to secure a living wage that she was suffering from a rights violation?

Practitioners used to dealing with the seemingly clear rights of individuals under the ICCPR were accustomed to asking questions about State actions that appeared to flow directly from the right guaranteed. For instance, the right to be free from torture implied the question, "Have individuals in a given state been subjected to torture?" The answer to this question would almost always determine whether a right had been violated or not: if there was a case of torture, there was almost always a violation. ${ }^{40}$ Conversely, the same form of question seemed not to address crucial issues with respect to ESC rights: if a practitioner asked whether people in a given State were working for a wage that would not support a decent life, the answer to the question might-or might notdetermine whether there was a violation of the right. This was because a State, for example, could be earnestly working to set up a minimum wage regime while large numbers of individual workers still suffered. Such earnest and

39. For a discussion of obligations of conduct and obligations of result in the context of ESC rights, see CRAVEN, supra note 22, at 107-09.

40. Of course this assumed simplicity was misleading. An answer to the question of whether or not someone has been tortured will not necessarily answer the question of whether a State has violated the Covenant. Usually, the answer to the question of State compliance will come through the application of one of several standards that all require States to prevent, investigate, and punish those who have committed torture; whether a specific State has violated the Covenant or not will be determined based on its efforts to take these steps. In essence, then, the obligation not to torture entails obligations of both conduct and result. Further, certain treaties, including the Convention Against Torture and Other Cruel, Inhuman or Degrading Treatment or Punishment, adopted and opened for signature Dec. 10, 1984, 23 I.L.M. 1027 [hereinafter CAT] (entered into force June 26, 1987), apply only to certain acts of torture: those carried out by or with the acquiescence of a State official with specific enumerated aims. See id. ant. 1 (qualifying the definition of torture with the requirement that the acts must have been carried out "for such purposes as obtaining from him or a third person information or a confession, punishing him for an act he or a third person has committed or is suspected of having committed, or intimidating or coercing him or a third person, or for any reason based on discrimination of any kind" and have been "inflicted by or at the instigation of or with the consent or acquiescence of a public official or other person acting in an official capacity."). 
concrete steps by a State would suggest that the State was living up to its obligation to "recognize" the right and thus was not violating the treaty. On the other hand, the State could be turning a blind eye to the problem, taking no action to improve workers' wages, a situation that would suggest the State was not "recognizing" the rights of those under its jurisdiction, and thus presumably was violating the Covenant.

Over the years, the differences between these categories of rights, ${ }^{41}$ and between the thresholds of "violation" and "fulfillment" have diminished. 42 Concepts, tools, and analytical frameworks developed in one realm have migrated across regimes to apply in the other. ${ }^{43}$ A detailed examination of such

41. For example, consider the way in which even the obligations of "conduct" and obligations of "result"-once thought to demonstrate the difference between ESC rights and civil and political rights-came to be understood as implicated in both regimes. Compare, e.g., ECOSOC, CESCR, The Nature of States Parties' Obligations, General Comment No. 3 (1990), reprinted in Compilation of General Comments and General Recommendations Adopted by Human Rights Treaty Bodies, supra note 31, at 18 [hereinafter General Comment No. 3] (stressing that the Convention includes obligations of conduct and result), with HRC, Article 6: The Right to Life, General Comment No. 6 (1982), reprinted in Compilation of General Comments and General Recommendations Adopted by Human Rights Treaty Bodies, supra note 31, at 114 (specifying obligations of result, 'such as not imposing the death penalty except as punishment for the "most serious crimes," as well as obligations of conduct, including effective investigations into cases of missing and "disappeared" persons and measures to reduce infant mortality). In the end, the difference is best understood as one of emphasis rather than one of kind. The decline of the result/conduct bifurcation as an explanatory tool has been echoed in the work of the International Law Commission as well. While the distinction was included in the First Reading of the Draft Articles on State Responsibility, it was rejected on the Second Reading in 1999 and omitted in the final version. See James Crawford, Introduction to INT'L L. COMM'N, THE INTERNATIONAL LAW COMMISSION'S ARTICLES ON STATE RESPONSIBILITY: INTRODUCTION, TEXT AND COMMENTARIES 1, $20-22$ (2002); see also id. at 344 (distinction between obligations of conduct and result deleted but "indirectly reflected" in art. 12 and its commentary).

42. There was once a debate in the literature about whether a "violations approach" was appropriate to the ICESCR. Audrey Chapman, the main proponent of this approach, argued that the CESCR should focus on identifying violations of the ICESCR, rather than attempting to assess compliance with the treaty's norm of progressive implementation. See Chapman, supra note 29. Distinctions between these two purported "approaches" have become less important over time, though the CESCR does now clearly point out actions-or omissions-that would count as violations under the Covenant in its General Comments. See, e.g., OHCHR, CESCR, Outline for Drafting General Comments on Specific Rights of the ICESCR (1999), http:/www.unhchr.ch/ $\mathrm{html} / \mathrm{menu} 2 / 6 /$ cescrnote.htm\#outline (including "Violations" as one of the core elements of the Committee's General Comments).

43. Perhaps the most striking example of this cross-fertilization comes in the "respect, protect, fulfill" rubric introduced to the U.N. human rights world by G.J.H. van Hoof and based on the work of Henry Shue. See G.J.H. van Hoof, The Legal Nature of Economic, Social and Cultural Rights: $A$ Rebuttal of Some Traditional Views, in THE RIGHT TO FOOD 97 (Philip Alston \& Katarina Tomasevski eds., 1984). Once thought to apply only to ESC rights, this framework is now invoked by advocates, treaty bodies, and other human rights mechanisms to describe the duties of governments for the whole spectrum of rights. See, e.g., Amnesty Int'l, Respect, Protect, Fulfill Women's Human Rights: State Responsibility for Abuses by 'Non-State Actors', AI Index IOR 50/001/2000, Sept. 1, 2000 (advocacy document using, inter alia, the "respect, protect, fulfill" rubric to describe the State's duties for abuses by non-State actors); HUMAN RIGHTS WATCH, TAINTED HARVEST: CHILD LABOR AND OBSTACLES TO ORGANIZING ON ECUADOR'S BANANA PLANTATIONS 
migrations and cross-fertilization is beyond the scope of this Article; what is significant here is that practitioners faced with the reality of doing ESC rights work felt they needed new tools. Indicators were one of the tools to which they turned, since they seemed to promise a way to monitor whether the State's conduct resulted in the fulfillment of individual and group rights. ${ }^{44}$

Ironically, at roughly the same time that ESC rights advocates began the difficult task of articulating the connections between indicators and rights, social scientists interested in applying statistical tools to civil and political rights assumed that ESC advocates-unlike civil and political rights advocatesalready had the data they needed to assess the degree to which ESC rights were being fulfilled. To these social scientists, practitioners studying ESC rights were miles ahead, since they could presumably rely upon the widely available social and economic indicators used by such international development organizations as the U.N. Development Programme (UNDP) and the World Bank, as well as the definitions and concepts used in those contexts. Goldstein posited that

The area of social and economic rights lends itself to much easier definition and operationalization than the political, civil, and personal security rights area. Thus, there is general agreement on the definition of terms such as infant mortality, life expectancy, and caloric intake. ${ }^{45}$

\section{Similarly, Richard Claude and Thomas Jabine asserted that}

On the whole nations provide enough data of moderate to good quality on these subjects so that anyone who wants to can determine how well the citizens of a country are faring with respect to economic, social, and cultural rights included in the Universal Declaration and, at least roughly, how they compare with people in other countries. ${ }^{46}$

5 (2002) (applying the "respect, protect, fulfill" framework to rights under the ICCPR); Comm. on Elimination of Discrimination Against Women, Report of the Committee on the Elimination of Discrimination Against Women, $20^{\text {th }}$ and $21^{s t}$ Session, 3-7, U.N. Doc. A/54/38/Rev.1 (Jan. 1, 1999) (describing States Parties' obligations to respect, protect, and fulfill women's right to health); Special Rapporteur Jiri Dienstbier, Situation of Human Rights in the Former Yugoslavia: Report of Jiri Dienstbier, Special Rapporteur of the Commission on Human Rights on the Situation of Human Rights in Bosnia and Herzegovina, the Republic of Croatia and the Federal Republic of Yugoslavia, U.N. Doc. E/CN.4/1999/42 (Jan. 20, 1999) (using the respect, protect, fulfill standard in relation to human rights concerns in the former Yugoslavia); see also CRAVEN, supra note 22, at 109-14 (arguing that the rubric is applicable to civil and political rights as well as ESC rights), and Sandra Fredman, The Structure of Positive Duties in HUMAN RIGHTS TRANSFORMED: POSITIVE RIGHTS AND POSITIVE DUTIES 65-91 (2008).

44. In another incarnation of the cross-fertilization referred to above, indicators have migrated back across the ESC boundary and are being developed to monitor certain civil and political rights as well. See, e.g., UNIFEM South Asia Regional Office, CEDAW Indicators for South Asia: An Initiative, (Aug. 2004), http://www.unifem.org.in/PDF/CEDAW_Indicators.pdf (including indicators concerning civil and political rights, such as the right to equal participation in political and public life and the right to equal protection of the law); see also discussion infra Section IV.

45. Robert Justin Goldstein, The Limitations of Using Quantitative Data in Studying Human Rights Abuses, in Human RIGHTS AND Statistics: GetTING THE RECORD STRAIGHT 35, 40 (Thomas B. Jabine \& Richard P. Claude eds., 1992).

46. Richard P. Claude \& Thomas B. Jabine, Exploring Human Rights with Statistics, in HUMAN RightS AND StaTISTICS: GeTting THE RECORD StRAight, supra note 45, at 5, 13. 
Civil and political rights researchers were convinced that they needed what they thought ESC advocates already had: measurement tools that would enable cross-national comparisons. To achieve this, they sought to create single or composite assessments of human rights performance: indicators, or sets of indicators, that would measure the status of civil and political rights in a given country. There were two especially well-known and controversial efforts. The first was an annual report entitled Freedom in the World: Political Rights and Civil Liberties, which was produced by the Washington-based nongovernmental organization Freedom House. This report used two variables (called "political rights" and "civil liberties," which were further disaggregated into "checklists") to assign numerical scores to countries in order to compare their relative "freedom." 47 Second, Charles Humana's World Human Rights Guide assigned percentage ratings to countries based on scores concerning forty human rights. Countries were then labeled "good, fair, poor, or bad." 48

Civil and political rights analysts were also interested in establishing causal connections between a State's human rights performance and other conditions such as economic development or form of government. Their struggle was first to identify which violations should be counted in this composite assessment as representative of a country's essential civil and political rights performance. Andrew McNitt, for instance, suggested that a "core" set of civil and political rights (specifically, "freedom from torture, freedom from imprisonment for the mere expression of a belief, and freedom from political execution") should be used to measure the single phenomenon of "human rights" performance across nations. $^{49}$

Once representative violations were agreed upon, other concerns were identified that seemed especially challenging in relation to civil and political rights measurement. The most pressing of these concerns were data reliability

47. Freedom House, Freedom in the World, http://www.freedomhouse.org/template.cfm?page $=15$ (last visited Sept. 30,2008). The methodology used to arrive at the numerical scores can be briefly summarized this way: Freedom House developed two checklists (one concerning political rights, the other pertaining to civil liberties), which are applied to each country under review by a survey team. For example, the political rights checklist contained, inter alia, items such as "Is the head of state and/or head of government or other chief authority elected through free and fair elections?" and "Are the legislative representatives elected through free and fair elections?" In response to these questions, the team assigns 0 to 4 points per item on the checklist, with some variation allowed for situations of "extreme violence." Countries are then placed in the categories "free," "partly free," and "not free" based on their numerical scores. The methodology has varied somewhat over the years, but has stayed generally true to this approach. See Freedom House, Methodology (2006), http://www.freedomhouse.org/template. $\mathrm{cfm}$ ?page=35\&year=2006.

48. Charles Humana, World Human Rights Guide (1986); Charles Humana, World HUMAN RIGHTS GUIDE (1983).

49. Andrew D. McNitt, Some Thoughts on the Systematic Measurement of the Abuse of Human Rights, in HUMAN RIGHTS: THEORY AND MEASUREMENT 89, 93 (David Louis Cingranelli ed., 1988); see also Kathleen Pritchard, Comparative Human Rights: Promise and Practice, in HUMAN Rights: THEORY AND MEASUREMENT, 139 (David Louis Cingranelli ed., 1988); George A. Lopez \& Michael Stohl, Problems of Concept and Measurement in the Study of Human Rights, in HUMAN RightS AND STATISTICS: GETTING THE RECORD STRAIGHT, supra note 45, at 216, 224-25. 
and availability across nations. As Robert Goldstein noted, "Where data are available, they will often be extremely difficult and expensive to obtain and are likely to be fragmentary, controversial, or of dubious reliability."50 This was true since governments were likely to hide data concerning civil and political rights violations (such as the number of deaths in custody), or to never have collected such data at all (such as the number of cases of torture). ${ }^{51}$ Finally, researchers attempted to develop statistical models that would allow them to draw conclusions about causality. For example, Kathleen Pritchard used path analysis to "provide information about the underlying causal process of human rights," suggesting relationships of causality between economic resources, judicial independence, "constitutional acknowledgment" and "overall human rights conditions." 52

Thus, as civil and political rights researchers struggled with how to acquire valid and reliable data across nations and to construct composite assessments that would allow comparisons of relative levels of "freedom," they assumed that many of the problems they encountered had already been resolved in relation to ESC rights. ${ }^{53}$ What they did not recognize was that social and economic indicators were designed to measure relative national levels of human development and not the compliance with, and fulfillment of, ESC rights. ${ }^{54}$

50. Goldstein, supra note 45 , at 41 .

51. See McNitt, supra note 49, at 95-96. Samuelson and Spirer suggest a methodology for assessing incomplete, distorted, and missing data concerning human rights issues. Douglas Samuelson \& Herbert F. Spirer, Use of Incomplete and Distorted Data in Making Inferences About Human Rights Violations, in HUMAN RIGHTS AND STATISTICS: GETTING THE RECORD STRAIGHT, supra note 45 , at 62 .

52. Pritchard, supra note 49 , at $144-46$.

53. For a discussion of more recent initiatives to create "justice and human rights indicators," see Bard A. Andressen et al., Justice and Human Rights Indicators: Towards an Operational Framework (May 2006), available at

http:/www.jus.uio.no/forskning/grupper/humrdev/indicators.html (background paper for a workshop on developing justice and human rights indicators); and Workshop on Developing Just. \& Hum. Rts. Indicators, Just. \& Hum. Rts. Initiative, Workshop Report (May 2006), available at

http:/www.jus.uio.no/forskning/grupper/humrdev/indicators.html (report from workshop on developing justice and human rights indicators).

54. Throughout this period, of course, CPR researchers were cognizant of the problems inherent in constructing composite assessments, relying on simplistic quantitative measures, and in any effort to compare disparate national situations in relation to one another. Russel Barsh was a particularly thorough critic. See Russel Barsh, Measuring Human Rights: Problems of Methodology and Purpose, 15 HuM. RTS. Q. 87 (1993).

Goldstein also disparaged a number of these efforts:

The danger posed by an excessive and automatic quantitative orientation to all problems - a sort of quantitative fetishism-can be clearly demonstrated by referring to several recent publications which have attempted to develop schemes for comparing overall human rights violation levels between different countries. . . . Barnett Rubin and Paula Newberg seriously state that a fundamental 'dilemma' in human rights research is to determine 'how many reports of torture are equivalent to a murder'; Gloria Valencia-Weber and Robert Weber suggest a formula which answers such a question by equating 70 murders with 100 'disappearances'; and Kenneth Bollen 


\title{
C. Measuring Implementation: "Available Resources," Immediate Obligations, and Indications of Progress
}

A second major difference in the way the ICCPR and the ICESCR are crafted is in the way the State's obligations are described. The relevant articles in each Covenant describe the obligations quite differently:

\section{ICCPR, Article 2(1)}

Each State Party to the present Covenant undertakes to respect and to ensure to all individuals within its territory and subject to its jurisdiction the rights recognized in the present Covenant ...

\section{ICESCR, Article 2(1)}

Each State Party to the present Covenant undertakes to take steps, individually and through international assistance and cooperation, especially economic and technical, to the maximum of its available resources, with a view to achieving progressively the full realization of the rights recognized in the present Covenant by all appropriate means....

The difference between the obligation "to respect and to ensure" Covenant rights and the duty to "take steps ... to the maximum of [the State's] available resources with a view to achieving progressively" the Covenant rights has been much analyzed. ${ }^{55}$ Commentators long feared that the progressive realization

\begin{abstract}
suggests creating a system whereby a hypothetical country might be assigned a baseline score of 100 with regard to, for example, freedom of party organization, and then ' $a$ real country judged to have party liberties a fifth of the standard would receive a score of twenty while one 18 times greater would have 1800 as a value.' John McCamant reports having actually carried out such an endeavor, and that, for example, with regard to the overall human rights climate, he concluded that East Germany was 'probably 200 times more severe in 1976 than was the Federal Republic of Germany, but Uganda was still 100 times worse.' Chile, under Pinochet was assessed as 10 times more repressive than the Philippines and ' 100 times worse than India.'
\end{abstract}

Goldstein, supra note 45, at 49-50; see also Lopez \& Stohl, supra note 49 (critiquing ranking exercises that do not situate their analyses in political context, and calling for multiple "dimensions" of composite assessments); James McCormick \& Neil J. Mitchell, Human Rights Violations, Umbrella Concepts, and Empirical Analysis, 49 WORLD POLS. 510 (1997) (arguing that the "umbrella concept" of "repression of human rights" must be disaggregated into discrete violations). For a recent rejection of attempts to create composite assessments, see Philip Alston, Richard Lillich Memorial Lecture: Promoting the Accountability of Members of the New UN Human Rights Council, 15 J. TRANSNAT'L L. \& POL'Y 49, 87 (2005) (noting that 'very few experts-be they economists, statisticians, or human rights specialists - consider that a composite index of human rights performance is likely to be feasible, credible or useful in the foreseeable future"). For examples of very recent social science considerations of the use of quantitative methods in human rights contexts, see Statistical METHOdS FOR HUMAN RightS (Jana Asher, David Banks \& Fritz J. Scheuren eds., 2008).

55. See, e.g., Chapman, supra note 29, at 23 (asserting that "Progressive realization,' the current standard used to assess state compliance with economic, social, and cultural rights, is inexact and renders these rights difficult to monitor"). But see Leckie, supra note 28, at 92-95 (stressing that the progressive realization provisions of the ICESCR should not be misconstrued to diminish the specific legal obligations placed on States under the Covenant). 
and resource limitations provisions would be used to excuse States' inaction. ${ }^{56}$ Others were concerned that these provisions inherently limited the ability to measure States' compliance. ${ }^{57}$ For the purpose of this Article, the significance lies less in the type of obligations imposed on States Parties than in the linked question of how such different obligations should best be measured. ${ }^{58}$ Here is where indicators entered the picture for economic and social rights practitioners.

In 1990, Danilo Türk, then U.N. Special Rapporteur on the Realization of Economic, Social and Cultural Rights, reported on the possibility of using indicators to measure ESC rights. ${ }^{59}$ He suggested that indicators could be useful in the following ways, stressing in particular their role in progressive realization:

The use of indicators within the field of economic, social and cultural rights can, if applied in a precise and systematic manner, contribute to the realization of these rights in a variety of ways. Indeed, without the availability of a measurement device based on some form of statistical data, there is little chance of obtaining an overall picture which shows the extent which these rights are realized. Indicators can provide one means of assessing progress over time towards the "progressive realization" of these norms. Additionally, indicators can help to reveal some of the difficulties associated with fulfilling these rights. They can assist in the development of the "core contents" of some of the less developed rights in this domain, and can provide a basis from which a "minimum threshold approach" can be developed. Indicators can reveal information about the extent to which certain rights are enjoyed or not enjoyed within the gambit of States, information which might not generally be available if other forms of measuring progress were employed. Similarly, they can provide yardsticks whereby countries can compare their own progress with that of other countries, especially countries at the same level of socio-economic development. ${ }^{60}$

Thus, indicators were seen as a way of measuring progress over time, of capturing the extent to which ESC rights were being realized—and thus enjoyed by the beneficiaries of these rights-and of helping to develop the core content of ESC rights. Indicators were also seen as a way of allowing for comparison across countries, and within countries across time. It is important to note, however, that this early exploration was framed in terms of the use of traditional social and economic indicators-data sets developed by social scientists and economists-in the human rights context. ${ }^{61}$

56. See, e.g., Robert E. Robertson, Measuring State Compliance with the Obligation to Devote the "Maximum Available Resources" to Realizing Economic, Social and Cultural Rights, 16 HUMAN RTS. Q. 693, 694 (1994).

57. See Chapman, supra note 29 , at 31 .

58. For a careful consideration of methods for measuring compliance with the "maximum available resources" obligation, see Robertson, supra note 56.

59. Special Rapporteur Danilo Türk, The New International Economic Order and the Promotion of Human Rights, Realization of Economic, Social and Cultural Rights, Progress Report Prepared by Mr. Danilo Türk, Special Rapporteur, U.N. Doc. E/CN.4/Sub.2/1990/19 (July 6, 1990).

60. Id. 77.

61. See id. T9 7-30. Todd Landman argues that "[d]evelopment indicators are thus seen as suitable proxy measures to capture the degree to which states are implementing these [human rights] 
The Special Rapporteur's early identification of indicators as a possible way to make the seemingly vague obligations of States Parties to the ICESCR more concrete is echoed in the early work of the CESCR surrounding the treaty obligation that each State take steps "to the maximum of its available resources." For practitioners schooled in the seemingly absolute standards of civil and political rights, this term seemed to inject an unacceptable degree of subjectivity into the question of treaty compliance. What counted as "available" resources, and how would the threshold for "maximum" be determined? Who would make these determinations, for that matter? Finally, were there any scientific and objective standards upon which to base these assessments?

In response to these questions and the resulting crisis of legitimacy they posed for the ESC rights regime, the CESCR answered in two principal ways: first, by referring to immediate obligations under the Covenant, and second, by requiring States to monitor their own progress toward full realization of rights for all in a way that would be reviewable by the Committee. Concerning the first response, the CESCR made clear in its General Comment on the Nature of States Parties' obligations (No. 3, 1990) that States must immediately ensure that everyone is enjoying the "minimum essential levels of each right":

On the basis of the extensive experience gained by the Committee, as well as by the body that preceded it, over a period of more than a decade of examining States parties' reports the Committee is of the view that a minimum core obligation to ensure the satisfaction of, at the very least, minimum essential levels of each of the rights is incumbent upon every State party. Thus, for example, a State party in which any significant number of individuals is deprived of essential foodstuffs, of essential primary health care, of basic shelter and housing, or of the most basic forms of education is, prima facie, failing to discharge its obligations under the Covenant. If the Covenant were to be read in such a way as not to establish such a minimum core obligation, it would be largely deprived of its raison d'être. By the same token, it must be noted that any assessment as to whether a State has discharged its minimum core obligation must also take account of resource constraints applying within the country concerned. Article 2 (1) obligates each State party to take the necessary steps "to the maximum of its available resources". In order for a State party to be able to attribute its failure to meet at least its minimum core obligations to a lack of available resources it must demonstrate that every effort has been made to use all resources that are at its disposition in an effort to satisfy, as a matter of priority, those minimum obligations. ${ }^{62}$

States, therefore, were immediately responsible for meeting a minimum core obligation for each right; the substance of those cores remained-and in many instances, still remains--under development. ${ }^{63}$ In the meantime,

obligations. For example, literacy rates and gender breakdown of educational attainment are seen as proxy measures of the right to education. . " TODD LANDMAN, STUDYING HUMAN Rights 90 (2006).

62. Supra note 41.

63. See Leckie, supra note 28, at 100-02. For an excellent recent discussion of the minimum core approach, see Katharine G. Young, The Minimum Core of Economic and Social Rights: A Concept in Search of Content, 33 YALE J. INT'L. L. 113 (2008). 
however, the minimum core concept was to act as a burden-shifting device in reporting before the Committee: if a State asserted that it had been unable to meet the minimum core obligation due to resource constraints, it was up to that State to demonstrate that it had attempted to use all available resources for the purpose of ensuring core rights for all. Similarly, the Committee asserted that there was an immediate obligation on all States Parties to ensure that ESC rights were guaranteed without discrimination, and to ensure that judicial and other State organs recognized non-discrimination and other immediately implementable obligations as justiciable. ${ }^{64}$

The CESCR made a second important move to counter concerns about the vagueness of the "maximum available resources" clause: it called on States to set up adequate means of monitoring their own progress in ensuring ESC rights for all. Here, the Committee reminded States that they must continually make good faith efforts to guarantee ESC rights for all, and that these efforts should be measurable:

The Committee wishes to emphasize, however, that even where the available resources are demonstrably inadequate, the obligation remains for a State party to strive to ensure the widest possible enjoyment of the relevant rights under the prevailing circumstances. Moreover, the obligations to monitor the extent of the realization, or more especially of the non-realization, of economic, social and cultural rights, and to devise strategies and programmes for their promotion, are not in any way eliminated as a result of resource constraints. ${ }^{65}$

While States were not obliged by the treaty text to adopt any particular method for documenting and monitoring their progress in implementing Covenant rights, the Committee suggested-very early on-that they should use benchmarks ${ }^{66}$ as "indication[s] of progress":

[I]t may be useful for States to identify specific bench-marks or goals against which their performance in a given area can be assessed. Thus, for example, it is

64. General Comment No. 3, supra note 41, 15.

65. Id. $\ 11$.

66. There has been extensive discussion in human rights circles of the difference between indicators and benchmarks. As Green has written, "[b]enchmarks can be defined as goals or targets that are specific to the individual circumstances of each country. As opposed to human rights indicators, which measure human rights observation or enjoyment in absolute terms, human rights benchmarks measure performance relative to individually defined standards." Green, supra note 2 , at 1080 n.45. Prominent ESC rights analysts have proposed various procedures in which international indicators would be developed and national benchmarks agreed upon. The distinction between benchmarks and indicators is, for the purposes of this Article, less relevant than the distinction between universal and nation-specific measurement devices. However, it should be noted that such persistent efforts to fix in place the differences between indicators and benchmarks highlight the former's tendency to become conflated with the latter. We discuss this issue substantively below in Section III, but it is worth noting here that similar concerns often emerge in human rights debates in terms of the procedures for the creation of indicators and benchmarks. See, e.g., Green, supra note 2, at $1081 \mathrm{n} .48$; Interview with Philip Alston in New York, NY (Oct. 16, 2002) (suggesting a process in which the various treaty bodies would adopt an approved procedure for the creation of benchmarks, States would identify benchmarks using that procedure, and the treaty body would monitor their implementation over time). 
generally agreed that it is important to set specific goals with respect to the reduction of infant mortality, the extent of vaccination of children, the intake of calories per person, the number of persons per health care provider, etc. In many of these areas, global bench-marks are of limited use, whereas national or other more specific bench-marks can provide an extremely valuable indication of progress. ${ }^{67}$

Although the examples given above are quantitative, the Committee underlined the importance of qualitative data as well, noting that "it is clear that qualitative, as well as quantitative, data are required in order for an adequate assessment of the situation to be made." 68 Importantly, these benchmarks were to be created and applied by the States, with the Committee in a supervisory, reviewing role. Finally-and perhaps most significantly for our purposeswhile resource constraints could therefore legitimately have explained a State's inability to fully implement each right for all individuals, they would not be allowed to excuse a failure to monitor State efforts toward full realization of ESC rights.

A few years after the CESCR made these recommendations, a U.N. seminar on "appropriate indicators to measure achievements in the progressive realization of economic, social and cultural rights" was held, in preparation for the World Conference on Human Rights in Vienna in 1993. Convened on the basis of a recommendation from the then-Special Rapporteur on the Realization of Economic, Social and Cultural Rights in 1990 that more work be done to encourage the use of indicators in ESC rights contexts, the seminar assigned to itself the goal of "[s]etting ideal indicators for each of the substantive rights in the International Covenant on Economic, Social and Cultural Rights drawing upon the work on indicators that had been carried out by the United Nations and its agencies . . . "69 Evident in this formulation is the expectation-similar to that expressed above by the Special Rapporteur in 1990-that indicators created in the development context could be drawn upon and perhaps imported into the human rights context-for monitoring (enjoyment or compliance with) human rights standards.

During the workshop, some key issues surfaced that will be explored in later in this Article. First, the problem of what was being "indicated" arose and

67. ECOSOC, CESCR, General Comment No. 1, Reporting by States Parties (1989), reprinted in Compilation of General Comments and General Recommendations Adopted by Human Rights Treaty Bodies, supra note 31, 16 , at 14.

68. Id. I 7, at 14. Nancy Thede makes a similar point in Nancy Thede, Human Rights and Statistics-Some Reflections on the No-Man's-Land Between Concept and Indicator, 18 STAT. J. U.N. ECON. COMM'N FOR EUR. 259, at 271 (2001) (calling for the "fostering [of] a culture of statistics amongst international human rights and democracy organizations and national partners in the field," and noting further that "[o]ur overriding concern must be how to ensure that [sets of] common indicators effectively bind together both quantitative data and its qualitative interpretation ... to ensure ...that the analysis is not 'shaved off' [to leave us] with the bare statistics.").

69. World Conference on Human Rights, Apr. 19-30, 1993, Report on the Seminar on Appropriate Indicators to Measure Achievements in the Progressive Realization of Economic, Social and Cultural Rights, I 3, U.N. Doc. A/CONF.157/PC/73 (Apr. 20, 1993). 
appeared to be elided, as demonstrated in the "and" emphasized in the following passage from the conference report:

Following the suggestion of the Special Rapporteur, the seminar decided that it would focus on developing indicators to assess the progressive realization of economic, social and cultural rights and, more specifically, to monitor States parties' compliance with their obligations under the International Covenant on Economic, Social and Cultural Rights. ${ }^{70}$

What then would be "indicated"-realization/enjoyment of rights, or compliance with the treaty? The imprecision exemplified in this sentence would surface repeatedly during the workshop and would not be resolved.

The second major issue evident in the conference report is closely tied to the first: the lack of clarity concerning the substantive content of the various rights under discussion was seen as a severe constraint in developing indicators. The problem was summarized this way:

A clear definition and consensus of what had to be assessed was considered to be a conditio sine qua non for the use of indicators. On numerous occasions the fact was brought up that some economic, social and cultural rights needed more conceptualization, which in itself was seen as a limitation in the use and application of indicators. Although some thought that there was more need for standard setting and further elaboration of certain categories, others thought that human rights standards were firmly in place. It was questioned how disaggregation could be achieved if some rights were not well defined. . . ${ }^{71}$

The third relevant concern that emerged during the workshop was a worry about the apparent privileging of quantitative data over qualitative information when designing and applying indicators: "Quantitative measures obscured the qualitative and subjective nature of human rights . ...72 However, the contours of the "subjective" nature of human rights were not discussed at length at the workshop.

The final relevant issue raised in the 1993 seminar was embodied in the conclusions of the conference: instead of producing a set of indicators to measure the core ESC rights, the conference concluded that it was impossibleat that early stage of the development of ESC rights-to identify and agree on indicators.

The seminar concluded that the first priority was to identify and clarify the content of the various rights and obligations. Only then would it be possible to identify the most appropriate way to assess progressive achievement, which may or may not involve the use of statistical indicators. ${ }^{73}$

Thus, the seminar ended with a non-conclusion: called together to agree on a set of indicators, the participants instead agreed that it was too early to identify

70. Id. $\ 12$ (emphasis added).

71. Id. ๆ 142.

72. Id. ๆ 108.

73. Id. 14. 
appropriate indicators for rights whose contents remained indeterminate. ${ }^{74}$

\section{Indeterminacy, Indicators, and the Turn Toward Monitoring of Monitoring ${ }^{75}$}

In the intervening years, the CESCR has developed a fairly consistent approach to using indicators in its monitoring role. The Committee has continually requested that States Parties develop and apply indicators to monitor their own progress in implementing various provisions of the treaty. For example, when reviewing Australia's progress in 1993, the Committee recommended "that due attention be given to the development of indicators for measuring progress in the implementation of the rights covered by articles 13 to 15 of the Covenant." 76 Similarly, the Committee chided Georgia for failing to identify and use indicators during the economic transition: "A lack of clearly established guidelines and indicators hinders the transition process." Committee has also congratulated States on effective use of indicators, as exemplified in this comment concerning Norway: "the Committee welcomes the adoption by the Ministry of Local Government and Labour of a plan of action which provides, inter alia, for the development of indicators for measuring racial discrimination ...."78

In its General Recommendations, the Committee on Economic, Social and Cultural Rights (CESCR) has taken a further step, placing the major onus of proof on States to demonstrate either that they have set up monitoring systems, including - but not limited to-indicators, in relation to certain rights, or that they are not needed. ${ }^{79}$ In its General Comment on the Right to Education, the

74. The Vienna Declaration and Program of Action recommended that "a system of indicators" should be developed to "measure progress in the realization of the rights set forth in the International Covenant on Economic, Social and Cultural Rights." See Vienna Declaration and Programme of Action, supra note 19, at 98.

75. In a paper presented at the IAOS Conference on "Statistics, Development and Human Rights" in Montreux, Switzerland in 2000, Thomas Hammarberg described the tendency of treaty monitoring bodies to "monitor the monitoring." See Thomas Hammarberg, Searching for the Truth: The Need to Monitor Human Rights with Relevant and Reliable Means, 18 STAT. J. U.N. ECON. COMM'N FOR EUR. 131, 134 (2001).

76. ECOSOC, CESCR, Consideration of Reports Submitted by States Parties Under Articles 16 and 17 of the Covenant, Concluding Observations of the Committee on Economic, Social and Cultural Rights, Australia, \1 16, U.N. Doc. E/C.12/1993/9 (June 3, 1993).

77. ECOSOC, CESCR, Consideration of Reports Submitted by States Parties Under Articles 16 and 17 of the Covenant, Concluding Observations of the Committee on Economic, Social and Cultural Rights, Georgia, ๆ 8, U.N. Doc. E/C.12/1/Add.42 (May 17, 2000).

78. ECOSOC, CESCR, Consideration of Reports Submitted by States Parties Under Articles 16 and 17 of the Covenant, Concluding Observations of the Committee on Economic, Social and Cultural Rights, Norway, I 8, U.N. Doc. E/C.12/1995/13 (Dec. 28, 1995).

79. The Committee on the Rights of the Child (CRC) has taken a similar approach to the use of indicators, though a thorough consideration of its practices in this regard is beyond the scope of this Article. By way of a tentative description, the CRC has requested that States Parties develop and apply indicators to monitor the various provisions of the Convention on the Rights of the Child. See Comm. on the Rights of the Child, General Guidelines Regarding the Form and Content of 


\section{Committee found that:}

The State party has an immediate obligation "to take steps" (art. 2(1)) towards the realization of secondary, higher and fundamental education for all those within its jurisdiction. At a minimum, the State party is required to adopt and implement a national educational strategy which includes the provision of secondary, higher and fundamental education in accordance with the Covenant. This strategy should include mechanisms, such as indicators and benchmarks on the right to education, by which progress can be closely monitored ${ }^{80}$

This approach was echoed in the Committee's 2000 General Comment on the Right to the highest attainable standard of health, in which the Committee called on States Parties to use indicators as part of their national strategies for achieving the right to health. ${ }^{81}$ The duty to so monitor was also examined from the opposite side: in the same General Comment, the CESCR asserted that a State's failure to demonstratively monitor could amount to a violation of the

Initial Reports to be Submitted by States Parties Under Article 44, Paragraph 1(a), of the Convention, 99 7, 18, 20, 22, 24, U.N. Doc. CRC/C/5 (Oct. 30, 1991) (requesting the inclusion of indicators and statistical data in initial reports); CRC, General Guidelines Regarding the Form and Contents of Periodic Reports to be Submitted by States Parties Under Article 44, Paragraph $1(\mathrm{~b})$, of

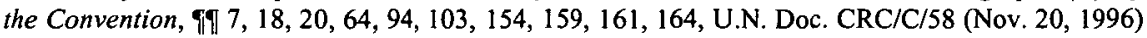
(requesting the identification and inclusion of indicators in periodic reports); CRC, Consideration of Reports Submitted by States Parties Under Article 44 of the Convention, Initial Reports of States Parties Due in 1997, Addendum, Bolivia, U.N. Doc. CRC/C/15/Add.I (July 24, 1997) (recommending the use of indicators); CRC, Consideration of Reports Submitted by States Parties Under Article 44 of the Convention, Convention on the Rights of the Child, Concluding Observations of the Committee on the Rights of the Child, Cape Verde, \13, U.N. Doc. CRC/C/15/Add.168 (July 11, 2001) (suggesting the identification and use of indicators); CRC, Consideration of Reports Submitted by States Parties Under Article 44 of the Convention, Convention on the Rights of the Child, Concluding Observations of the Committee on the Rights of the Child, Norway, I17, U.N. Doc. CRC/C/15/Add.23 (Apr. 25, 1994) (same). It is worth noting that unlike their sibling bodies, the CEDAW, CERD and Human Rights Committees appear not to use indicators consistently, and appear not to have made their development a requirement, or even a consistent suggestion to States under review. Those bodies do, however, use statistics in one way or another. We believe there is a useful distinction to be drawn between the ways in which the CRC and the CESCR, on the one hand, and the Human Rights Committee, CEDAW, and CERD, on the other, tend to use statistics and indicators. The difference lies in the ways in which the different treaty monitoring bodies have-or have not - integrated the responsibility to create and/or use indicators into the very obligations States have under the various human rights treaties. The CRC and the CESCR now ask States Parties to design and use indicators to monitor the implementation of Convention rights. The other treaty bodies seek statistical information as part of their overall consideration of the situation in the country under examination. Surveying the use of statistical information and indicators by U.N. treaty bodies, Maria Green notes that all of the U.N. treaty bodies ask for statistical information, and sometimes use the term "indicator" to describe this data. See Green, supra note 2, at 1091-94.

80. ECOSOC, CESCR, General Comment No. 13, The Right to Education, 1 52, U.N. Doc. E/C.12/1999/10 (Dec. 8, 1999).

81. States were urged "to adopt and implement a national public health strategy and plan of action, on the basis of epidemiological evidence, addressing the health concerns of the whole population; the strategy and plan of action shall be devised and periodically reviewed, on the basis of a participatory and transparent process; they shall include methods, such as right to health indicators and benchmarks, by which progress can be closely monitored . ..." ECOSOC, CESCR, General Comment No. 14, The Right to the Highest Attainable Standard of Health, 53, U.N. Doc. E/C.12/2000/4 (Aug. 11, 2000). 


\section{Covenant:}

Violations of the obligation to fulfill [the right to health] occur through the failure of States parties to take all necessary steps to ensure the realization of the right to health. Examples include the failure to adopt or implement a national health policy designed to ensure the right to health for everyone; insufficient expenditure or misallocation of public resources which results in the nonenjoyment of the right to health by individuals or groups, particularly the vulnerable or marginalized; the failure to monitor the realization of the right to health at the national level, for example by identifying right to health indicators and benchmarks...82

Once States have identified appropriate indicators, the Committee explains, they should also "set appropriate national benchmarks in relation to each indicator." 83 Then, "[d]uring the periodic reporting procedure the Committee will engage in a process of scoping with the State party" whereby the Committee will assess the indicators and benchmarks, and the State's progress using those indicators. ${ }^{84}$ This duty to monitor is echoed again in the Committee's 2002 General Comment on the Right to Water:

To assist the monitoring process, right to water indicators should be identified in the national water strategies or plans of action. The indicators should be designed to monitor, at the national and international levels, the State party's obligations under articles 11, paragraph 1 , and 12. Indicators should address the different components of adequate water (such as sufficiency, safety and acceptability, affordability and physical accessibility), be disaggregated by the prohibited grounds of discrimination, and cover all persons residing in the State party's jurisdiction or under their control ... Having identified appropriate right to water indicators, States parties are invited to set appropriate national benchmarks in relation to each indicator. During the periodic reporting procedure, the Committee will engage in a process of "scoping" with the State party. ${ }^{85}$

Very similar language calling on States to create indicators, set benchmarks, and engage in scoping appears in each of the most recent general comments from the CESCR: the 2005 General Comments on the Equal Right of Men and Women to the Enjoyment of All Economic, Social and Cultural Rights, ${ }^{86}$ the Right to Work, ${ }^{87}$ and the Right of Everyone to Benefit from the Protection of the Moral and Material Interests Resulting from any Scientific, Literary or Artistic Production of which He or She is the Author, ${ }^{88}$ and the 2008

82. Id. ๆ 52.

83. Id. ๆ 58.

84. Id.

85. ECOSOC, CESCR, General Comment No. 15 (2002), The Right to Water, \ 54, U.N. Doc. E/C.12/2002/11 (Jan. 20, 2003).

86. ECOSOC, CESCR, General Comment No. 16 (2005), The Equal Right of Men and Women to the Enjoyment of All Economic, Social and Cultural Rights, I39, U.N. Doc. E/C.12/GC/16 (Aug. $11,2005)$.

87. ECOSOC, CESCR, The Right to Work, General Comment No. 18, ๆๆ 46-47, U.N. Doc. E/C.12/GC/18 (Feb. 6, 2006) [hereinafter General Comment No. 18].

88. ECOSOC, CESCR, General Comment No. 17 (2005), The Right of Everyone to Benefit From the Protection of the Moral and Material Interests Resulting From Any Scientific, Literary or 
General Comment on the Right to Social Security. ${ }^{89}$ In its latest general comment, on the Right to Social Security, the CESCR identified the failure to monitor the substantive right under consideration as a violation of the obligation to fulfill that right, and the creation and use of indicators is the only monitoring device specifically identified by the CESCR. ${ }^{90}$

The step the CESCR has taken in the last fifteen years or so-from suggesting to States that benchmarks might be "useful" in 1990, to asserting that the creation and use of monitoring systems including indicators is a treaty obligation from 1999 onward-is striking. In effect, it shifts the onus of conceptualizing and applying indicators from the international community to the States themselves. In relation to indicators, then, the Committee's most vital role has become the highly technical one of monitoring the State's monitoring. ${ }^{91}$

It is important to note, however, that despite the apparently consistent assertion by the CESCR that it is the State's duty to develop and apply its own monitoring measures, and the Committee's duty to review the use of such indicators by the State, the CESCR continued to express hope that universally applicable, rights-specific indicators could be developed. In 1999, the CESCR proposed that a workshop be held on indicators and benchmarks for the right to education. In the proposal, the Committee asserted that the outcome of the 1993 workshop on indicators-which ended with agreement on the fact that the content of ESC rights were as yet too indeterminate - led it to conclude that "the next step is to focus on indicators in relation to specific economic, social and cultural rights," a focus that would result in "identification and agreement on

Artistic Production of which He or She Is the Author, If 49-50, U.N. Doc. E/C.12/GC/17 (Jan. 12, 2006).

89. ECOSOC, CESCR, General Comment No. 19, The Right to Social Security, q1 74-76, U.N. Doc. E/C.12/GC/19 (Feb. 4, 2008).

90. General Comment No. 18, supra note 87, ๆ 36.

91. In its periodic review of State reports, the Committee has recently called on States to create and use indicators. See, e.g., ECOSOC, CESCR, Consideration of Reports Submitted by State Parties Under Articles 16 and 17 of the Covenant, Concluding Observations of the Committee on Economic, Social and Cultural Rights, Latvia, I 49, U.N. Doc. E/C.12/LVA/CO/1 (Jan. 7, 2008); ECOSOC, CESCR, Consideration of Reports Submitted by State Parties Under Articles 16 and 17 of the Covenant, Concluding Observations of the Committee on Economic, Social and Cultural Rights, Paraguay, Ifl 23, 30, U.N. Doc. E/C.12/PGY/CO/3 (Jan. 4, 2008); ECOSOC, CESCR, Consideration of Reports Submitted by State Parties Under Articles 16 and 17 of the Covenant, Concluding Observations of the Committee on Economic, Social and Cultural Rights, El Salvador, 7 36, U.N. Doc. E/C.12/SLV/CO/2 (June 27, 2007); ECOSOC, CESCR, Consideration of Reports Submitted by State Parties Under Articles 16 and 17 of the Covenant, Concluding Observations of the Committee on Economic, Social and Cultural Rights, Liechtenstein, 35, U.N. Doc. E/C.12/LIE/CO/1 (June 9, 2006); ECOSOC, CESCR, Consideration of Reports Submitted by State Parties Under Articles 16 and 17 of the Covenant, Concluding Observations of the Committee on Economic, Social and Cultural Rights, Mexico, 94, U.N. Doc. E/C.12/MEX/CO/4 (June 9, 2006); ECOSOC, CESCR, Consideration of Reports Submitted by State Parties Under Articles 16 and 17 of the Covenant, Concluding Observations of the Committee on Economic, Social and Cultural Rights, Bosnia and Herzegovina, \49, U.N. Doc. E/C.12/BIH/CO/1 (Jan. 24, 2006). 
key [ESC rights] indicators." 92 As will be explored in Section IV below, the U.N. Office of the High Commissioner for Human Rights is currently engaged in a project aimed at making this hope concrete. Several years ago, the chairpersons of the various human rights treaty bodies-including the chairperson of the CESCR-requested that the OHCHR construct indicators for key human rights enshrined in the international human rights treaties. Since then, professional staff of the OHCHR, together with experts gathered from a variety of disciplines, have been hard at work constructing indicators to measure the efforts of States and the enjoyment of human rights all over the world. Those efforts will be discussed in Section IV. First, Section III will consider the CESCR's turn toward monitoring of monitoring, suggesting that insights from social scientists who have identified similar shifts in other areas may be usefully applied to human rights indicators.

\section{III.}

AUdit, DistancE, AND THE PROBLEM WITH TRUSTING INDICATORS

Leaving unresolved the question of whether to construct transnational or national indicators allowed the CESCR to hold in abeyance the difficult choice between either fully inhabiting the role of rights compliance monitors or completely embracing States Parties' control of the mechanics of measurement, thereby consigning itself primarily to the position of auditor. To understand how human rights indicators function as an audit practice, and further, to understand how audit practices bring human rights treaty bodies into the world of global governance, it will be useful to take a brief detour away from legal scholarship and into the social studies of science and technology.

\section{A. Indicators as Audit Practice}

In 1994, economic analyst Michael Power identified what he called an "audit explosion," which he described as having "roots in a programmatic restructuring of organizational life and a new 'rationality of governance.",93 For Power, the audit, with its financial accounting origins, exemplified both literally and metaphorically a number of monitoring and control practices characteristic of late modern social organization such as inspections, assessments, and other evaluative technologies.

Audit has become a benchmark for securing the legitimacy of organizational action in which auditable standards of performance have been created not merely to provide for substantive internal improvements to the quality of service but to make these improvements externally verifiable via acts of certification. ${ }^{94}$

92. ECOSOC, CESCR, Proposal of the Committee for a Workshop on Indicators, Benchmarks and the Right to Education, Annex No. VIII, U.N. Doc. E/C.12/1999/11 (1999).

93. POWER, supra note 10 , at 10 (quoting Rose \& Miller, supra note 5).

94. Id. at 10-11. 
Social scientists have noted that systems of auditing-and in particular the language of quantification-are demanded when the following three conditions exist. One, there is "a relation of accountability" in which one party is mandated to provide an account of itself to another. ${ }^{95}$ Two, "the relation of accountability must be complex such that [auditors] are distant from the actions of [auditees] and are unable personally to verify them." 96 Three, there are conditions of mutual distrust between the auditor and the auditee. ${ }^{97}$ In the field of human rights, all three conditions are met. First, States that have ratified the principal human rights conventions are required to provide to the various treaty bodies periodic accounts of their efforts to ensure those rights. Second, particularly in the international realm, distance between parties is created and maintained along numerous axes, including geography, language, culture, economic capacities, etc. Third, distrust is common on the part of human rights monitors concerning governmental self-representation in the context of rights fulfillment and reporting. At the same time, States frequently mistrust those responsible for monitoring their human rights performance.

The best that the ESCR Committee could do at this stage of its work was to maintain a balance between mutually mistrusting parties - the auditor (in this case, the treaty body) and the auditee (in this case, the States Parties). In ways that foreshadowed the tight-rope-walking solutions arrived at by the OHCHR in the latter body's subsequent efforts, the Committee effectively maintained this balance concerning the need for universal indicators by turning to an audit-like structure. On one hand, a comprehensive set of international indicators created by the Committee might have been perceived as an imposition, suggesting the Committee's mistrust of States Parties. This may have resulted in an exacerbation of any existing mistrust that States Parties had of the Committee. In their favor, a set of international indicators could, by their very appearance of cross-national comparability, have offered the imprimatur of objectivity. If identical indicators were to be applied transnationally, no single State could argue it had been subjected to unreasonable, or unfairly targeted, standards of accountability. Uniformity would serve as a symbol of impartiality.

On the other hand, a series of nationally-constructed indicators, while allowing for important cultural and economic specificity, could by this very specificity risk appearing to both States and international treaty bodies as arbitrary. This is in part because indicators are assumed to be valuable only insofar as they are cross-nationally comparable. ${ }^{98}$ Nation-specific indicators

95. Id. at 5, (citing David Flint, Philosophy AND PRINCIPLes OF AUditing (1988)).

96. Id. at 5 .

97. Id.; Porter, supra notes 1 and 17.

98. Hans-Otto Sano identifies "[c]omparative and ranking assessment" as one of several purposes for human rights indicators. See Hans-Otto Sano, Human Rights Indicators: Purpose and Validity, Paper for Turku/Åbo Expert Meeting on Human Rights Indicators, 11-13 March 2005, (Mar. 2005), available at www.abo.fi/instut/imr/research/seminars/indicators/Human.doc. Similarly, Kate Raworth identifies the desire for "cross-country comparisons" as driving human 
might also risk exacerbating the Committee's mistrust of States Parties, since the work done to link the rights with the indicators might appear to provide opportunities for political manipulation.

The decision to abdicate the task of developing international indicators in favor of assigning itself the role of monitoring States' indicators effortshanding off the task of indicator development to States themselves-was a rather neat solution, and a remarkable transformation for the Committee. In this way, through the above-described processes, the Committee shifted its position from that of direct monitor of States' compliance with human rights treaty obligations-including the obligation to ensure that promised rights were being enjoyed - to that of auditor. The Committee required States to develop and implement procedures to monitor themselves for appropriate compliance and guaranteed rights enjoyment, while the Committee in turn would monitor the States' own monitoring. For our purposes, however, it is most notable that the Committee undertook so important a shift in roles with so little discussion of its significance or ramifications. ${ }^{99}$

\section{B. The Problems with Trusting Indicators}

What are the ramifications of the Committee's removal from direct, substantive monitoring to what global governance scholars, to whom we shall turn later in this Article, have called "rule at a distance"? What significance can be read from the Committee's effective abdication of one form of authority in favor of another in this instance? The significance lies in audits as a technology of control.

The explosive demand for "indicators" that can be used to determine the degree to which States are living up to their human rights obligations is intimately connected with the trust in data that is understood to be abstract, quantifiable, and putatively transferable. The demands arise both from the quest within international human rights circles for better ways to hold governments to account, and from the proliferation of certain types of verification and monitoring methods becoming popular in a wide range of business, non-profit, and governmental management fields. ${ }^{100}$ Indicators embody both the strengths and weaknesses of auditing practices.

rights indicators projects, though she concludes that universal indicators are neither possible nor desirable. See Kate Raworth, Measuring Human Rights, in PERSPECTIVES ON HEALTH AND HUMAN RIGHTS 393, 404-11 (Sofia Gruskin et al. eds., 2005).

99. For a critique of the CESCR's approach in the context of the right to health, see Audrey R. Chapman, The Status of Efforts to Monitor Economic, Social, and Cultural Rights, in ECONOMIC RIGHTS: CONCEPTUAL MEASUREMENT, AND POLICY ISSUES 143-81, 161 (Shareen Hertel \& Lanse Minkler eds., 2007) ("Although admirable in its conceptualization, this process is problematic for its implementation. The dilemma, of course, is that the states parties are in no better position than the Committee to develop rights-based health indicators. Nor does the Committee have the expertise, let alone the time, to engage in the scoping process envisioned in the General Comment.").

100. POWER, supra note 10, at 4-6. 
Audit practices entail "sampling, reliance on external expertise, and the assessment of internal control systems." As Power argues,

[a]udits have value because they seek to draw general conclusions from a limited examination of the domain under investigation. But despite statistically credible foundations for sampling, audit practice is driven by economic pressures to derive more, or at least as much, assurance from fewer inputs ... . Reliance on other experts enables the unauditable to be auditable by creating a chain of opinions in which the auditor distances himself from the first order judgments of the expert .

.. [R]eliance on others substitutes for directly checking the thing itself. ${ }^{101}$

Audits - and in our case, indicators-are further constrained by the limits of measurability and affordability. One U.N. staff member involved in the creation of indicators concerning children's rights explained: "People try to get the information that they can. What is available? What information can you get? Because if you can't get this information, you can't get it." 102 For instance, if vaccinating children has been determined to enhance their right to the highest attainable standard of health, one could use as an indicator the number of children vaccinated. This is a number that would usually be inexpensive and easy to obtain. However, in a country like Bosnia-Herzegovina, where there was a dearth of post-war census information, such a number would also be meaningless, since the percentage of the total population of children who have been vaccinated could not be calculated. As former CESCR Chair Philip Alston explained, "For the most part, [indicators] are essentially statistical in nature. That in turn means that their subject matter must be potentially quantifiable, not only in a technical sense but in practical terms as well." 103

Chief among our concerns is the seemingly inevitable drift from this persistent demand for "potentially quantifiable" information to situations in which technical questions end up playing a more determinative role in the choice of human rights indicators than more substantive considerations of the best way to assess rights. As the critics of quantification cited in this Article have pointed out, questions such as "Can it be counted? If so, when and how? How accurately? By whom?" are never merely technical. There are a number of important conceptual problems that beset measurement by indicator as wellproblems that should be considered by human rights practitioners. When the Special Rapporteur on the Realization of Economic, Social and Cultural Rights made a plea in 1990 for statistical data ("without the availability of a measurement device based on some form of statistical data, there is little chance

101. Id. at 12 .

102. Interview by Rosga with Yulia Krieger, UNICEF Program Officer, UNICEF BosniaHerzegovina, in Sarajevo, Bosnia-Herzegovina (Nov. 9, 2002) (conceming the use of indicators in rights-based development programming).

103. Green, supra note 2, at 1077 (quoting Philip Alston, Concluding Observations, in BENCHMARKS FOR THE REALIZATION OF ECONOMIC, SOCIAL AND CULTURAL RIGHTS: A ROUNDTABLE Discussion ORganized by THE High COMmissioner for Human Rights, Geneva, Mar. 25,1998 ). Fukuda-Parr et al. also note the problem of gaps in data availability. Fukuda-Parr et al., supra note 12 , at $7-8$. 
of obtaining an overall picture which shows the extent which these rights are realized"), he was evincing a widespread preference for quantitative over qualitative measures. ${ }^{104}$ This is consistent with the post-Enlightenment development of discourses of objectivity, in which "suspicion of certain aspects of subjectivity-namely, of 'interpretation, selectivity, artistry, and judgment itself -became . . . a prominent feature of objectivity in science." 105 And "scientization," as Evan Schofer calls the increasing reliance on social scientific consultants and organizations by NGOs, is rampant internationally.

[T]his trend toward the "scientization" of social activity is particularly pronounced at the international level, where world-polity values of rationality and universalism are strong. . . . There is a tendency in both lay and academic discussion to treat the scientization of social planning and governance as a purely instrumental response to the efficacy of science. While this is certainly the case in many domains, it is hardly the whole story. Much scientization takes place in domains where there is little scientific consensus or the efficacy of science is questionable - e.g. . . [ [concerning] issues of economic underdevelopment. ${ }^{106}$

But numbers, statistics, and the language of quantification generally are seen as uniquely capable of reducing or eliminating subjectivity. In his seminal history of the association between objectivity and quantification, Theodore Porter observed that "quantification is a technology of distance" 107 :

The language of mathematics is highly structured and rule-bound. . . In public and scientific uses ... [it] has long been almost synonymous with rigor and universality. Since the rules for collecting and manipulating numbers are widely shared, they can easily be transported across oceans and continents and used to co-ordinate activities or settle disputes. Perhaps most crucially, reliance on numbers and quantitative manipulation minimizes the need for intimate knowledge and personal trust. Quantification is well suited for communication that goes beyond the boundaries of locality and community. 108

Thus, the reliance on the language of quantification rests on an assumption that quantification will - at least partially - solve the problem of mistrust. The presentation of neatly tabulated numbers erases the means and messiness of their own generation. ${ }^{109}$ It obscures evidence of the human judgment involved in

104. Turk, supra note 59.

105. Alan Megill, Four Senses of Objectivity, in RETHINKING OBJECTIVITY, supra note 17, at 11 (quoting Lorraine Daston and Peter Galison, The Image of Objectivity, 40 REPRESENTATIONS 81, 98 (1992)).

106. Evan Schofer, Science Associations in the International Sphere, 1875-1990: The Rationalization of Science and the Scientization of Society, in CONSTRUCTING WORLD CULTURE: INTERNATIONAL NONGOVERNMENTAL ORGANIZATIONS SINCE 1875, 249, 264 (John Boli \& George M. Thomas eds., 1999).

107. PORTER, supra note 1 , at ix.

108. Id.

109. Describing the process by which indicators were developed for an assessment BosniaHerzegovina's fulfillment of certain children's rights obligations, a UNICEF staff person explained: "It [was] such an ad hoc thing how this [production of indicators] worked. [A handful of employees from different U.N. agencies] sort of all [sat] down and agreed on these indicators. Then [they were] translated into Bosnian and ... the [Bosnian] consultants [took them] to their own government 
statistical production.

No one in the human rights field pretends that indicators can ever really be apolitical, but the need for information that is as accurate, reliable, and meaningful as possible is pressing. Unfortunately, discussions of criteria for good indicators tend not to specify which form of objectivity is at work. Wendy Lesser identifies two different senses of objectivity: the first sense of objectivity is the "sense that an objective report is disinterested, honest, reliable, impartial." 110 The second sense of the term suggests that "only something which is not subjective - which does not partake of the individual human viewpoint - can be fully objective, neutrally conveying things and events that are out in the world without the distorting coloration of human consciousness." 111 Lesser points out that only a machine (her example is a television camera) can ever hope to approach the second sense:

And even that possibility seems remote . . for in order to become a functional picture of reality, even television's images need to be absorbed by our particular minds. The picture itself can have no meaning until viewers make something of it. ... 112

But humans, with human judgment and interpretation, she reminds us, are necessary for the first sense. "I depend on people to give objective-in the sense of disinterested and impartial-interpretations to videotape .... Objectivity, in the first of the two senses, is a quality that only the human mind can have." 13

institutions to consult ... saying, 'What do you think? Are there any other ones you want?' The ... local consultants [had to insist] on [unified] methodology [because] here, the statistical institute sometimes uses different methodologies and different entities from the same data. [Findings aren't even] comparable at the state level." Krieger, supra note 102. As this comment suggests, the dual assumptions that (a) social science methodologies-even statistical ones-are universal, and (b) similar types of data are, or should be, equally available everywhere, are disproved in practice.

110. WENDY LESSER, Pictures at an EXECUTION: AN INQUIRY INTO THE SUBJECT OF MURDER 139 (1993).

111. Id.

112. Id.

113. Id. Of course, exegeses and critiques of various conceptions of objectivity are numerous and reflect considerably more complexity and nuance than Lesser's more succinct summation here. For a sampling across disciplines, see KENT GREENAWALT, LAW AND OBJECTIVITY (1992); Marsha P. Hanen, Feminism, Objectivity, and Legal Truth, in Feminist Perspectives: PhILOSOPHICAL ESSAYS ON METHODS AND MORALS 29 (Lorraine Code, Sheila Mullett \& Christine Overall eds., 1988); Sandra Harding, Rethinking Standpoint Epistemology: What is "Strong Objectivity?," in FEMINIST EPISTEMOLOGIES 49 (Linda Alcoff \& Elizabeth Potter eds., 1993); OBJECTIVITY AND ITS OTHER (Wolfgang Natter, Theodore R. Schatzki \& John Paul Jones III eds., 1995); RETHINKING OBJECTIVITY, supra note 17 (an especially useful collection of essays); and RICHARD RORTY, OBJeCtivity, RelativisM, AND TRUTH: PHILOSOPHICAL PAPERS VOlUME I (1991). For a particularly important trio of sources outlining the key fault-lines of political and methodological debates about the uses of the languages of objectivity, along with some possible bridging strategies, see DONNA HARAWAY, Situated Knowledges: The Science Question in Feminism and the Privilege of Partial Perspective, in Simlans, Cyborgs, and Women: The Reinvention of Nature 183 (1991); and the conversation between Robin West and Barbara Hermstein Smith in the following publications: Barbara Herrnstein Smith, The Unquiet Judge: Activism Without Objectivism in Law and Politics, in ReTHINKING OBJeCtivity, supra note 17, at 289; and Robin West, Relativism, 
Discussions of "objective" indicators are vulnerable to both the tendencies to conflate these two senses of objectivity (valuing less those indicators which require obvious human interpretation, such as qualitative assessments) and/or to privilege those (generally numerical) indicators whose interpretive work is invisible.

As discussed with regard to the work of the CESCR, chief among the strengths of auditing practices is their rhetorically powerful capacity for transferability. Indicators are said ideally to allow comparisons between nations at similar levels of economic development, and over time within a given nation. As Power puts it, "the general principles of quality control systems . . . can be made to look similar and enable them to be compared at an abstract level." 114

\section{Goodhart's Law: The Tendency for Measures to Become Targets}

Yet even to the degree indicators "can be made to look similar and ... compared at an abstract level," 115 acros $/$ geographical space, they tend to lose their efficacy as accurate and adequate measures over time. Scholars suggest that this is a characteristic of all measurement mechanisms that are tied to the goal of improvement. As the social anthropologist Marilyn Strathern puts it, "[w] hen a measure becomes a target, it ceases to be a good measure."116 Applied to the use of indicators in the human rights context, this principle explains the phenomenon of the "expectations gap"117 in which a nation's reporting of successful fulfillment of treaty obligations has a more or less distant relationship to the actual enjoyment of rights by its citizens.

[A]uditing works by virtue of actively creating the external organizational environment in which it operates. . . Audit is never purely neutral in its operations... New motivational structures emerge as auditees develop strategies to cope with being audited; it is important to be seen to comply with performance measurement systems while retaining as much autonomy as possible. ${ }^{118}$

Strathern cites an account by Haridimos Tsoukas to demonstrate this phenomenon:

Objectivity and Law, 99 Y ALE L.J. 1473 (1990).

114. POWER, supra note 10 , at 12.

115. Id.

116. Marilyn Strathern, 'Improving Ratings': Audit in the British University System, 5 EUR. REV. 305, 308 (1997) (referring to Keith Hoskin's discussion of the many possible applications of "Goodhart's law") (citing Keith Hoskin, The 'Awful Idea of Accountability': Inscribing People Into the Measurement of Objects, in ACCOUNTABILITY: POWER, ETHOS AND THE TECHNOLOGIES OF MANAGING 265 (Rolland Munro and Jan Mouritsen eds., 1996)). Goodhart's law originates in economic theory and describes the processes by which targets become measures in financial control practices. Goodhart's law, as paraphrased in PEARS CYCLOPAEDIA G27, G31 (1990), states that "[a]s soon as the government attempts to regulate any particular set of financial assets, these become unreliable as indicators of economic trends." See Michael Mclntyre, Lucidity and Science, Parts I, II, III (2000), http://www.atm.damtp.cam.ac.uk/people/mem/papers/LHCE/goodhart.html.

117. POWER, supra note 10, at 9-10.

118. Id. at 13 . 
In 1993, new regulations [required] local authorities in the UK. . .to publish indicators of output, no fewer than 152 of them, covering a variety of issues of local concern. The idea was, [Tsoukas] reports, to make councils' performance transparent and thus give them an incentive to improve their services. As a result, however ... . even though elderly people might want a deep freeze and microwave rather than food delivered by home helps, the number of home helps [was] the indicator for helping the elderly with their meals and an authority could only improve its recognised performance of help by providing the elderly with the very service they wanted less of, namely, more home helps. ... The language of indicators takes over the language of service. ${ }^{119}$

Applied to human rights indicators, this principle underlies the risk that, to the extent governments do actively try to meet benchmarks and standards set in relation to international human rights treaties, the incentive to demonstrate success-or, say, "progressive realization"-according to given indicators may become greater than any incentive to substantively ensure the fulfillment and/or enjoyment of human rights themselves. For example, efforts abound to measure States' compliance with the right to gender equality in education. A common indicator for this right is the ratio of girls to boys enrolled in primary education. ${ }^{120}$ Given that States will be rewarded for demonstrating narrow ratios, there is a built-in incentive to document female school enrollment. However, such figures do not allow substantive rights fulfillment to be assessed. Important contextual information that would do so includes the existence of curricula assessed as qualitatively equitable, the absence of sex segregation in schools, and actual school attendance of girls as compared to boys.

While the ratio of female to male enrollment may-when situated within sufficient contextual information - initially be a good indicator, the tendency for measures to become targets means that the link between the indicator and the right purportedly being measured attenuates over time. Thus, the demand for indicators to be "consistently measurable" carries with it an inherent weakness: applying the same indicators over time does not guarantee consistent measurement of rights fulfillment. Instead, indicators lose value as States adjust their practices to improve their standing according to those indicators.

An example from Rosga's ethnographic research will help to illustrate this point. ${ }^{121}$ Rosga was a participant-observer at a meeting of consultants and

119. Marilyn Strathern, The Tyranny of Transparency, 26(3) BRIT. ED. RES. J. 309, 314 (2000) (emphasis added).

120. For a discussion of this indicator, see Special Rapporteur Katarina Tomasevski, Annual Report of the Special Rapporteur on the Right to Education, Katarina Tomasevski, 91 40-43, submitted to Commission on Human Rights, E/CN.4/2002/60 (Jan. 7, 2002); and UNESCO, OVERCOMING OBSTACLES TO EDUCATING GIRLS (2002), available at hitp://www.unesco.org/ education/efa/wef_2000/strategy_sessions/session_I-2.shtml (last visited Mar. 2, 2009). Note also that the ratio of boys to girls in education is an indicator for Millennium Development Goal No. 3, "Promote Gender Equality and Empower Women." See UNDP, Goal 3: Promote Gender Equality and Empower Women, http://www.undp.org/mdg/goal3.shtml (last visited Mar. 2, 2009).

121. These data are taken from research for Rosga's book-in-progress, Trafficking in the Rule of Law: Police and Human Rights Advocates in Emerging Democracies. Detailed information on the field site and participants is omitted to protect informant confidentiality, per agreements made under 
representatives from intergovernmental and non-governmental human rights organizations who had gathered to discuss human trafficking indicators. All attendees had significant expertise on the topic of trafficking for exploitative labor, especially trafficking of women and children, and trafficking for the purpose of sexual exploitation. All were concerned with victims' rights. Much of the meeting was devoted to the question of data: both the need for more-and more accurate - information about human trafficking. ${ }^{122}$ In the following exchange taken from Rosga's field notes (regarding "the users of information" about human trafficking), the participants clearly articulate their concern with the way that indicators can, rather than simply providing information, come to shape governments' framing of social problems, and thereby their relative prioritization of resources.

Participant 1: [Noting that the quality of information changes over time as its producers become more skilled at formulating it strategically]: My first effort at collecting information [about human trafficking] was easiest because no one knew what I was talking about. My second effort was harder, because they [government agency representatives] were anticipating me. The third was worst because they were deliberately creating reality to suit their own ends. They understood by then the meaning of what they were saying about trafficking. In the beginning, no one knew or cared what the grounds were for the Minister of Security to claim there had been one victim of trafficking in the past year and for NGOs to say there had been sixty-nine. But in time they became aware of the consequences to themselves of painting particular kinds of pictures.

As this participant's succinct account of her experience with data collection suggests, while it is valuable in some respects to use the same indicators over time, as standardization produces the ability to make both transnational and longitudinal comparisons, there are accompanying downsides to standardization as well. Even as governments' infrastructure may in fact improve, enabling greater technical accuracy in the reporting of indicator-driven data, government reporters of such data will likely develop accompanying sophistication in their abilities to manipulate informational presentations, raising yet again the twin specters of trust and accountability. No amount of statistical finesse will eliminate the need to ask how much political manipulation is involved when governments respond to demands for information-all the more so to the degree that their answers actually do have an impact on their standing in the international community.

Protocol Number 0505.07 of the University of Colorado-Boulder's Human Research Committee.

122. Notably, the meeting participants defied any effort to sort them into professional categories. At various points in their careers, they had been advocates and experts-sometimes simultaneously, sometimes with deliberate separation between these roles. One participant had been a prominent "local" NGO member but was now an expert consultant working for intergovernmental organizations. Another was a leader in a regional anti-trafficking network and pursuing her Ph.D. in the social sciences. Yet another had worked in shelters with trafficking victims in her home country but now worked as an economics analyst for an IGO. 
IV.

ENTER THE EXPERTS: RENEWED EFFORTS TO CREATE INTERNATIONAL HUMAN RIGHTS INDICATORS

As foreshadowed in Section II above, the Committee on Economic, Social and Cultural Rights did not abandon its hopes for universal indicators when it assigned itself the role of auditor. Instead, it turned to experts for help. In 2005, the Chair of the CESCR, together with the chairpersons of the other U.N. human rights treaty bodies, requested the U.N. Office of the High Commissioner for Human Rights to study the issue of human rights indicators and produce a report on that topic for their consideration in 2006. ${ }^{123}$ The 2006 "Report on Indicators for Monitoring Compliance with International Human Rights Instruments" explained that during 2005 and 2006, the OHCHR embarked on a process aimed at determining whether the:

use of appropriate quantitative indicators for assessing the implementation of human rights-in what is essentially a qualitative and quasi-judicial exercisecould contribute to streamlining the process, enhance its transparency, make it more effective, reduce the reporting burden and above all improve follow-up on the recommendations and concluding observations, both at the committee, as well as the country, levels. ${ }^{124}$

In other words, the OHCHR was tasked with determining how quantitative data, organized as indicators, could be used to make the performance of a function that was admittedly "quasi-judicial"- the assessment of whether States were living up to their human rights commitments-more feasible, transparent, and effective. The nature of the "effectiveness" desired as an outcome of assessment is somewhat opaque: the use of indicators is sought to "improve follow-up on the recommendations and concluding observations" of the treaty bodies. Just what form this follow-up might take is never clearly specified, though presumably it involves States conforming with the treaty bodies' recommendations.

By asking the OHCHR-a body of professional staff mandated to support the work of the treaty bodies - to undertake the task of developing universal indicators for human rights, the treaty bodies were asking a group of human rights professionals to achieve what they themselves had been unable to do: to transform a judgment-laden process into one that appeared technical, scientific, and therefore-in the context in which the treaty bodies' authority is often in doubt-more legitimate. Embedded in the 2006 Report was the assumption that an "appropriate" set of indicators would at once garner the support of social scientists, States, and civil society. Having done this, such indicators could then be used by treaty bodies in what would appear to be a technical exercise of

123. OHCHR, Report on Indicators for Monitoring Compliance with International Human Rights Instruments, I 1, U.N. Doc. HRI/MC/2006/7 (May 11, 2006) [hereinafter 2006 Report on Indicators].

124. Id. $\mid 2$. 
application, moving the treaty bodies beyond mere auditing to actual assessment of State compliance with the human rights standards set out in the treaties. This would have two advantages. First, it would be an assessment that appeared to be objective because it was based on quantitative, scientifically validated methods, embodied in measurement indicators, rather than in more visibly subjective (and therefore more apparently open to politicization) exercises of human judgment. Second, this very focus on indicators would effectively foreground the endproduct of (apparently neutral) measurement made possible by indicators, in the form of conclusions concerning States' progress on rights, compliance with treaty obligations, and recommended next steps. Simultaneously, the focus on indicators would background the acts of interpretation necessary to transform abstractly worded international laws into human rights standards both capable of and appropriate for transnational measurement.

\section{A. The Troubled Authority of the Human Rights Treaty Bodies in International Law}

This ambitious goal - to create a set of indicators capable of attracting the agreement of States, human rights advocates, and social scientists-is understandable given the longstanding and unresolved issue of the status of the treaty bodies - and thus of their assessments - in international law. Indeed, the turn toward mechanics of measurement and notions of scientific objectivity may appear to offer a kind of authority that the treaty bodies have never been able to achieve through the "quasi-judicial exercise[s]" that make up their core functions.

As a general matter, the human rights treaty bodies were set up to monitor States' implementation of and compliance with the treaties to which they are parties. With the exception of the CESCR, provision for the composition, functions, and powers of each treaty body is set out in the instrument itself; ${ }^{125}$ the CESCR was created by the U.N. Economic and Social Council (ECOSOC) to carry out the monitoring functions described for it in the treaty. ${ }^{126}$ Each of the seven main treaty bodies review periodic State reports on their efforts to implement and comply with the treaties; five are empowered to review complaints from individuals; two can act pursuant to an inquiry procedure that allows them to investigate "grave" or "systematic" violations; and four have the ability to entertain complaints by one State concerning another (though no State

125. See ICCPR, supra note 23, arts. 28-45; CAT, supra note 40, arts. 17-24; Convention on the Elimination of All Forms of Discrimination Against Women arts. 17-22, opened for signature Dec. 18, 1979, 1240 U.N.T.S. 13 (entered into force Sept. 3, 1981); International Convention on the Elimination of All Forms of Racial Discrimination arts. 8-16, opened for signature Dec. 21, 1965, 660 U.N.T.S. 195 (entered into force Jan. 4, 1969); International Convention on the Protection of the Rights of All Migrant Workers and Members of their Families arts. 72-78, Dec. 18, 1990, 30 I.L.M 1517.

126. See OHCHR, Committee on Economic, Social and Cultural Rights, http:/www2.ohchr.org /english/bodies/cescr/index.htm (last visited Mar. 2, 2009). 
has ever utilized this procedure). ${ }^{127}$ Made up of independent experts elected by the States Parties, the treaty bodies meet for several short periods each year, during which they carry out their mandated functions. ${ }^{128}$

Over the years, the treaty bodies have become more and more evaluative in their approach. While their role was once understood to be almost entirely that of a supportive guide for States in implementing the treaties, the Committees now assess State performance through several procedures. ${ }^{129}$ All of the treaty bodies work pursuant to treaty-specific Rules of Procedure, and they all formally review State practice in hearings in which State representatives are invited to present their periodic reports and to answer questions from members of the treaty bodies. These sessions are called "constructive dialogues," and the official approach is non-adversarial, as the OHCHR explains:

This procedure is not adversarial and the committee does not pass judgment on the State party. Rather the aim is to engage in a constructive dialogue in order to assist the Government in its efforts to implement the treaty as fully and effectively as possible. The notion of constructive dialogue reflects the fact that the treaty bodies are not judicial bodies, but were created to monitor the implementation of the treaties and provide encouragement and advice to States. ${ }^{130}$

In practice, however, the "constructive" dialogues range from extremely collegial to quite contentious. They are followed by written concluding comments or observations, in which the Committees review both positive and negative aspects of the State Party's performance under the treaty. ${ }^{131}$ While the treaty bodies avoid overt findings of specific violations during this periodic review process, a number of the treaty bodies come very close to making such determinations. ${ }^{132}$ For example, the Human Rights Committee, which monitors the ICCPR, makes pointed statements of "concern" about specific practices or allegations, and follows those with recommendations for how the State can

127. OHCHR, Concept Paper on the High Commissioner's Proposal for a Unified Standing Treaty Body, ๆ 3, U.N. Doc. HRI/MC/2006/2 (Mar. 22, 2006) [hereinafter Concept Paper].

128. See generally $\mathrm{OHCHR}$, Human Rights Treaties Bodies, http://www2.ohchr.org/english/ bodies/treaty/index.htm (last visited Mar. 2, 2009).

129. See STEINER, ALSTON \& GOODMAN, supra note 22, at 844-918 (examining the changing role of the treaty bodies over time, using the Human Rights Committee as an example).

130. Concept Paper, supra note 127, 1131.

131. The treaty bodies only began issuing collective written concluding comments (or "concluding observations") in the 1990s, though some of the bodies allowed their members to submit written individual observations before that. For a discussion of the evolving nature of concluding comments, see Michael O'Flaherty, The Concluding Observations of United Nations Human Rights Treaty Bodies, 6 HUM. RTS. L. REv. 27 (2006).

132. Id. O'Flaherty summarizes the legal status of concluding comments as follows: "(a) They have no binding status for States; (b) Nevertheless, as outputs of the treaty bodies they have a notable authority, albeit ill-specified; (c) This authority is most apparent in situations where the treaty bodies pronounce on issues of violation of the treaties and where they otherwise purport to interpret treaty provisions; (d) The authority is less clear where the treaty bodies provide general advice on strategies for enhanced implementation of a treaty and when they opine on matters which seem to have little or nothing to do with the actual treaty obligations of the State Party." Id. at 36. 
ensure compliance with the treaty. ${ }^{133}$ In recent years, a number of treaty bodies have taken significant steps to follow up on these recommendations. ${ }^{134}$ Informally, NGOs often use concluding comments in their advocacy efforts, and they can become the subject of intense domestic and international pressure as a result.

As explored earlier in this Article, the treaty bodies also issue General Comments (also called General Recommendations by some treaty bodies). While General Comments began largely as vehicles to explain procedural matters or to provide guidance for States in preparing their reports to the committees, they have, over time, come to emphasize interpretation, explicating in some detail the substantive provisions of the relevant treaty. ${ }^{135}$ As a general matter, General Comments have become more and more reasoned, formally structured, and far-ranging. ${ }^{136}$ They have set out the content of key rights, articulated State duties in relation to those rights, and explored issues such as remedies and monitoring. Some famous General Comments have sought to resolve-in favor of broad human rights principles-basic issues in international law; when they have done so, some States have taken strong objection. ${ }^{137}$ Despite this, some General Comments have become extremely influential

133. See, e.g., HRC, Consideration of Reports Submitted by States Parties Under Article 40 of the Covenant, Concluding Observations of the Human Rights Committee, France, II 20, U.N. Doc. $\mathrm{CCPR} / \mathrm{C} / \mathrm{FRA} / \mathrm{CO} / 4$ (July 31 , 2008) (Human Rights Committee, reviewing report of France, stating that the Committee "is concerned by reports that foreign nationals have in fact been returned by the State party to such countries, and subjected to treatment that violates article 7 of the Covenant," and that, accordingly, "[t]he State party should ensure that the return of foreign nationals, including asylum seekers, is assessed through a fair process that effectively excludes the real risk that any person will face serious human rights violations upon his return.").

134. See Concept Paper, supra note 127, I 32; see also O'Flaherty, supra note 131, at 47-51.

135. See STEINER, ALSTON \& GOODMAN, supra note 22, at 877-84; see also Philip Alston, The Historical Origins of the Concept of 'General Comments' in Human Rights Law, in THE INTERNATIONAL LEGAL SYSTEM IN QUEST OF EQUITY AND UNIVERSALITY: LIBER AMICORUM GEORGES ABI-SAAB 763 (L. Boisson de Chazournes \& V. Gowland Debbas eds., 2001).

136. See STEINER, ALSTON \& GOODMAN, supra note 22, at 877-84.

137. Perhaps the most well-known example of such a controversy involves the Human Rights Committee's General Comment No. 24 on reservations to the ICCPR. Reservations are statements made by States at the time they ratify a treaty that purport to alter the legal content of the treaty being ratified. See Vienna Convention on the Law of Treaties, art. 2(d), May 23, 1969, 1155 U.N.T.S. 331. In General Comment No. 24, the Human Rights Committee asserted its power to review the validity of reservations to the ICCPR, and to sever-essentially to ignore-those reservations it determines are contrary to the object and purpose of the Covenant. See HRC, General Comment No. 24: Issues Relating to Reservations Made upon Ratification or Accession to the Covenant or the Optional Protocols Thereto, or in Relation to Declarations under Article 41 of the Covenant, U.N. Doc. CCPR/C/21/Rev.1/Add.6 (Nov. 4 1994). The United States, France, and the United Kingdom all lodged official objections to the General Comment. See HRC, Observations by the United Kingdom on General Comment No. 24," Annex No. VI(B), U.N. Doc. A/50/40 (Oct. 3, 1995); HRC, Observations by the United States of America on General Comment No. 24, Annex No. VI(A), U.N. Doc. A/50/40 (Oct. 3, 1995); HRC, Observations by France on General Comment No. 24 on Reservations to the ICCPR, Annex No. VI, U.N. Doc. A/51/40 (Apr. 13, 1997). 
through formal and informal channels by guiding State policies, ${ }^{138}$ influencing U.N. agency actions, ${ }^{139}$ and becoming the framework for NGO action. ${ }^{140}$

Treaty bodies that decide individual petitions have an even more judicial, or court-like role than those that do not. They must decide, based on written submissions by the petitioner and the responding State, whether there has been a violation of the relevant treaty, and if so, what actions the State should take to remedy the violation. ${ }^{141}$ Even at this, the height of the Committees' "quasijudicial" role, the decisions of the treaty bodies are not binding as a matter of treaty law. ${ }^{142}$ Despite this limitation, the normative impact of the treaty bodies' decisions is significant. ${ }^{143}$ As the OHCHR has explained:

It is through individual complaints that human rights are given concrete meaning. In the adjudication of individual cases, international norms that may otherwise seem general and abstract are put into practical effect. When applied to a person's real-life situation, the standards contained in international human rights treaties find their most direct application. The resulting body of decisions may guide States, non-governmental organizations (NGOs) and individuals in interpreting the contemporary meaning of the texts concerned. ${ }^{144}$

The decisions of the treaty bodies in individual cases often have a wideranging impact. Notwithstanding the formal non-binding nature of the Committees' recommendations, the relevant State may act in accordance with

138. For example, in 2006, the U.K. govermment recognized that there is a right to water under international law. See Press Release, U.K. Department for International Development [DFID], UK Recognises the Right to Water as Hilary Benn Launches Call for Global Action Plan to Solve Water Crisis (Nov. 6, 2006), available at http://www.dfid.gov.uk/news/files/pressreleases/human-devreport06.asp. It cited the CESCR's General Comment No. 15 on the Right to Water in its background document released at the time of the announcement. See DFID, THE HUMAN RIGHT To WATER 9ף/ 3-5 (2006), available at http://www.dfid.gov.uk/pubs/files/human-right-water.pdf.

139. See, e.g., UNDP, HUMAN DEVELOPMENT REPORT 2006: BEYOND SCARCITY: POWER, POVERTY AND THE GLOBAL WATER CRISIS 26, 60-74 (2006) (citing the CESCR's General Comment No. 15 on the Right to Water and setting out U.N. policies to support that right).

140. See, e.g., Center for human Rights \& Global Justice, Partners in Health, RFK CENTER FOR HUMAN RIGHTS, AND ZANMI LASANTE: WOCH NAN SOLEY: THE DENIAL OF THE RIGHT TO WATER IN HAITI 27 (2008), available at http://www.chrgj.org/publications/reports.htmil\#escr (describing the CESCR General Comment No. 15 on the Right to Water as the basis for a collaborative effort to document and denounce violations of the right to water in Haiti) (last visited Mar. 2, 2009).

141. OHCHR, Human Rights Treaty Bodies-Individual Communications, http://www2 ohchr. org/english/bodies/petitions/individual.htm (last visited Mar. 2, 2009).

142. Concept Paper, supra note 127, \34.

143. Some influential commentators have argued that the decisions of the treaty bodies in individual cases are much more than recommendations. See, e.g., MARTIN SCHEININ \& RAIJA HANSKI, LEADING CASES OF THE HUMAN RIGHTS COMMITTEE 22 (2003) (arguing that "it would be wrong to categorize the Committee's views as mere 'recommendations.' They are the end result of a quasi-judicial adversarial international body established and elected by the States Parties for the purpose of interpreting the provisions of the Covenant and monitoring compliance with them.").

144. Human Rights Treaty Bodies-Individual Communications, supra note 141, at introduction. 
them, extending compensation to victims, or changing laws or policies. ${ }^{145}$ Even when this is not the case, NGOs and other civil society actors often use such decisions as the basis for advocacy efforts.

Finally, General Comments, decisions in individual cases, and even concluding comments have been cited by international, ${ }^{146}$ regional, ${ }^{147}$ and domestic courts. ${ }^{148}$ For example, the International Court of Justice cited approvingly the reasoning of the Human Rights Committee in its Advisory Opinion on the Legal Consequences of the Construction of a Wall in the Occupied Palestinian Territory in 2004. ${ }^{149}$ In that case, the ICJ cited to individual cases, a General Comment, and concluding comments of the Human Rights Committee. ${ }^{150}$ Through such frequent and high-level references, the work of the treaty bodies takes on an authoritative quality that, at times, approaches that of an international court or tribunal.

Thus, the treaty bodies walk a difficult tightrope: constrained by positive international law, their greatest power is often normative. They are at the height of their authority when they are most persuasive, when their legal analysistheir judgment-is valued. A power based on persuasion can be severely limiting, however. In the case of indicators, as explored below, the treaty bodies seem to be hoping that the power of social science will have greater "compliance pull" than well-reasoned General Comments or persuasive decisions in individual cases.

\section{B. Expert Indicators: The OHCHR Indicators Initiative}

To carry out the task entrusted to it by the treaty bodies, the OHCHR itself turned to professionals, convening several meetings of experts from the academy, international agencies and non-governmental organizations, as well as members of the treaty bodies themselves, to discuss indicators. The goal of these meetings-held initially in August 2005 and March 2006, with follow up meetings in December 2006, ${ }^{151}$ December 2007, and April 2008 ${ }^{152}$ - was to

145. For a discussion of State responses to the decisions of the Human Rights Committee, see STEINER, ALSTON \& GOODMAN, supra note 22, at 913-14.

146. See, e.g., Prosecutor v. Tadic, Case No. ICTY-IT-94-1-T, Decision on Defence Motion for Interlocutory Appeal on Jurisdiction, I 45 (Oct. 2, 1995) (citing and deploying the reasoning of the Human Rights Committee as reflected in individual cases and a General Comment).

147. See, e.g., Kurt v. Turkey, 27 Eur. Ct. H.R. 373, I65 (1998) (referring to the case law of the Human Rights Committee concerning enforced disappearances).

148. See, e.g., State v. Makwanyane \& Mchunu, 1995 (6) BCLR (CC) (S. Afr.), reprinted in 16 HUM. RTS. L. J. 154, 160 (1995) (discussing, as an interpretive tool, the approach of the Human Rights Committee to the death penalty).

149. See Legal Consequences of the Construction of a Wall in the Occupied Palestinian Territory, Advisory Opinion, 2004 I.C.J. 131, fi 109-10, 136 (July 9).

150. See id. If 109 (individual cases), 110 (concluding comments), 136 (General Comment).

151. Satterthwaite was a participant at the December 2006 meeting.

152. OHCHR, Report on Indicators for Promoting and Monitoring the Implementation of 
design and adopt a conceptual framework for the creation and implementation of human rights indicators that could be used for "monitoring the compliance of State Parties with international human rights instruments" by the treaty bodies. ${ }^{153}$ Since the work was undertaken at the request of the treaty bodies, the 2006 Report assumed that the indicators being developed would be used by the treaty bodies in their assessment of State compliance with the relevant treaties.

The OHCHR had been working on human rights indicators even before this formal process began, drawing on analytical advances made by one of the independent experts then entrusted with work on a specific human rights issue, the U.N. Special Rapporteur on the Right to Health, Paul Hunt. ${ }^{154}$ In 2003, Hunt had proposed a conceptual framework and recommended approach to creating and using indicators in monitoring the right to health. ${ }^{155}$ This approach, which relied on three types of indicators-structural, process, and outcome-was later adopted by the OHCHR as the framework for its indicators project.

The result was a framework that made a significant contribution in terms of conceptually clarifying human rights compliance indicators, while also significantly scaling down expectations for the use of those indicators. ${ }^{156}$ Whereas the initial hope was, ambitiously, for a set of indicators that could be used for "monitoring compliance" with human rights treaties, ${ }^{157}$ the final product is a framework that "seeks neither to prepare a common list of indicators to be applied across all countries irrespective of their social, political and economic development, nor to make a case for building a global measure for cross-country comparisons on the realization of human rights." 158 Thus, through the experts' consultations, the goal of creating universally applicable indicators for the use of treaty bodies in measuring compliance with treaties was transformed into a framework and attendant list of illustrative indicators that

allows a balance between the use of a core set of human rights indicators that may

Human Rights, 15 n.17, U.N. Doc. HRI/MC/2008/3 (June 6, 2008) [hereinafter 2008 Report on Indicators].

153. Id. $\ 1$.

154. For a discussion of this work, see Report of the Special Rapporteur on the Right of Everyone to the Enjoyment of the Highest Attainable Standard of Physical and Mental Health, Paul Hunt, U.N. Doc. E/CN.4/2006/48, 14 (3 Mar. 2006) [hereinafter 2006 Hunt Report].

155. See Report of the Special Rapporteur on the Right of Everyone to the Enjoyment of the Highest Attainable Standard of Physical and Mental Health, Paul Hunt, U.N. Doc. A/58/427, 7-10 (10 Oct. 2003) [hereinafter 2003 Hunt Report].

156. For a discussion of various conceptual frameworks for the creation of human rights indicators, see Welling, supra note 3, at 947-53.

157. See 2006 Report on Indicators, supra note 123, If 12 ("In the use of indicators for monitoring the implementation of human rights, the first step should be to have a general agreement on the choice of indicators. This should be followed by setting performance benchmarks on those selected indicators.") (citations omitted).

158. 2008 Report on Indicators, supra note 152, ๆ 43. 
be universally relevant and at the same time retain the flexibility of a more detailed and focused assessment on certain attributes of the relevant human rights, depending on the requirements of a particular situation. ${ }^{159}$

In short, an effort that was initially aimed at giving the treaty bodies a new tool to help in the "quasi-judicial" exercise of assessing State compliance with treaties was transformed into an initiative aimed at giving all human rights practitioners a tool to conduct that assessment-implicitly now seen as a technical exercise.

At a conceptual level, the OHCHR's framework responds to a number of the concerns discussed in Section I of this Article. For example, the confusion over whether indicators would measure human rights enjoyment by populations under a State's jurisdiction or efforts made by States to fulfill their treaty obligations ${ }^{160}$ was resolved in favor of measuring both enjoyment and State effort in order to allow for assessment of compliance. The framework adopts the same approach for all rights-whether civil and political, or social, economic, and cultural - eschewing earlier divisions between types of rights. ${ }^{161}$ Each substantive right is broken down into several elements, or "characteristics" based on the normative content of the right as set out in relevant treaties and General Comments produced by the relevant treaty bodies. The framework adopted by the OHCHR therefore draws on the increasing conceptual clarity concerning the human rights set out in the core treaties. The right to life, for example, was given the following "attributes": arbitrary deprivation of life, disappearances of individuals, health and nutrition, and the death penalty. ${ }^{162}$ One of the limitations of this approach, of course, is that those rights that have not been as carefully explicated by the treaty bodies will not be as easily translated into the indicators framework. Several experts have suggested that indicators should be created only for those rights that have been the subject of at least one General Comment by the relevant treaty body. ${ }^{163}$ Otherwise, as our initial critique suggested and others also worry, the experts might, in effect, get ahead of the treaty bodies, articulating human rights norms and standards through their measurement indicators, rather than the other way around. ${ }^{164}$

Once attributes were identified for a given right, three types of indicators were designed for each right: structural, process, and outcome. Briefly, structural indicators "reflect the ratification and adoption of legal instruments and existence of basic institutional mechanisms deemed necessary for

159. Id.

160. For a discussion of this confusion in earlier efforts, see Raworth, supra note 98.

161. See 2008 Report on Indicators, supra note $152,95$.

162. See id. 17.

163. Personal communications with Satterthwaite.

164. A related concern is expressed by Todd Landman, who states that "Tremendous progress in human rights measurement has been achieved but there are serious and significant lacunae in the field that need to be addressed that include [. . . ] the content of rights that remain unmeasured. . " LANDMAN, supra note 61, at 91 (emphasis in original). 
facilitating realization of a human right. They capture commitments or the intent of the State in undertaking measures for the realization of the concerned human right." 165 Quite literally, these indicators include things like-for the right to adequate housing - "[i]nternational human rights instruments, relevant to the right to adequate housing, ratified by the State."166 Process indicators measure the efforts of States as they implement and enforce human rights; they measure things like the amount of money spent on a program to fulfill a given right, or the number of complaints processed by the authorities concerning alleged violations of the right being assessed. Process indicators are meant to capture the cause element of a cause and effect relationship between the efforts of States and the fulfillment of the right under examination. ${ }^{167}$ Outcome indicators, explained below, are meant to capture the effect element. Importantly, process indicators are said to be "more sensitive to changes than outcome indicators and hence are better at capturing progressive realization of the right or in reflecting the efforts of the State Parties in protecting the rights." 168

Outcome indicators aim to measure the actual enjoyment of the human right under consideration by the relevant population. Most of the familiar socioeconomic indicators can most prominently be found within this category. For example, in relation to the right to life, "life expectancy at birth" can be found alongside "number of deaths in custody per 1,000 detained or imprisoned persons, by cause of death (for example, illness, suicide, homicide)." ${ }^{169}$ If the appropriate process indicators have been chosen, there will be some form of cause and effect relationship between the State efforts measured by the process indicators and the fulfillment of rights measured by outcome indicators. ${ }^{170}$ By using all three types of indicators to measure an individual right, the idea is to "reflect the commitment-effort-results aspect of the realization of human rights through available quantifiable information."171. This cause and effect relationship may be among the hardest elements to achieve using the conceptual framework adopted by the OHCHR. This is true because understanding cause and effect requires extremely detailed, comprehensive, and context-specific analysis. ${ }^{172}$ As the framework stands, only "illustrative" indicators are chosen

165. See 2008 Report on Indicators, supra note 152, ๆ 18.

166. See id. at 29 .

167. See id. 19.

168. See id.

169. See id. at 22.

170. Former Special Rapporteur on the Right to Health Paul Hunt wams that it will not always be possible to capture cause and effect though indicators. See 2006 Hunt Report, supra note 154, I 59 .

171. See id. ๆ 17.

172. For a discussion of the difficulty of reflecting cause and effect through indicators, see ERIK ANDRE ANDERSEN \& HaNS-OTto SANO, DANISH INST. FOR HUM. RTS., HUMAN RIGHTS INDICATORS AT PROGRAMME AND PROJECT LEVEL - GUIDELINES FOR DEFINING INDICATORS, MONITORING AND EVALUATION (2006), available at http://www.humanrightsimpact.org/fileadmin /hria_resources/human_rights_indicators_at_prog_and_proj_level.pdf (discussing the difficulty of 
for any given right; it would therefore seem impossible to guarantee that a specific cause and effect relationship will be captured in relation to a specific right in a given country.

In the last two years, the OHCHR has piloted its framework and illustrative indicators through national and regional workshops. ${ }^{173}$ Through these consultations, the OHCHR has refined its procedural approach to developing and using human rights indicators. The result seems to be a significant emphasis on participation in the development and use of indicators. Whereas earlier work seemed to assume that experts at the international level could develop universal indicators that would apply across countries, the most recent report from the OHCHR calls for participation in the selection of indicators as an essential element of their use, though the means of such participation is not specified. ${ }^{174}$ While this participatory aspect is to be welcomed-indeed, as discussed in Section IV, it is essential-without more guidance, it also calls. into doubt the coherence of a framework that seeks to reflect certain kinds of relationships. If a group of stakeholders, for example, selects two or three process indicators that are not in any logical sense the "cause" of the outcome indicators also chosen, which body will make sense of the results?

properly "attributing" an impact to a specific intervention in the context of project management and evaluation). Furthermore, causal relationships in the social world are notoriously difficult to measure using non-experimental methods (methods without entirely known and strictly controlled variables). As sociologist Stanley Lieberson reminds us, "Empirical data can tell us what is happening far more readily than they can tell us why it is happening." STANLEY LIEBERSON, MAKING IT COUNT: THE IMPROVEMENT OF SOCIAL RESEARCH AND THEORY 219 (1987). Yet, "there is a tendency to make explained variance or the well-behaved data set a good in itself. As a consequence, the researcher is prone to judge the optimal outcome in terms of the closest fit or the most variance explained." Id. at 91. In other words, social researchers-often in spite of themselves-will tend to suggest that when "statistically significant" correlative relationships can be identified between an independent and dependent variable, and/or one independent variable can be associated much more strongly than another with a relevant dependent variable - that a causal relationship can be inferred from this finding. Of course, even when social researchers are very careful not to make such suggestions, consumers of social science data often draw causal inferences from correlative or associative data, in spite of researchers' strongest cautions to the contrary. Elaborating upon this general tendency, Lieberson identifies the following more specific dangers haunting non-experimental social research: First, in "pursuit of variance. . . researchers. . pick certain problems and ignore others, depending on whether they can obtain data sets that are 'appropriate' (i.e. that incorporate variation in the crucial variables). [And second,] . . the level of empirical analysis is often determined not simply by the substantive nature of the problem but by a statistical requirement, to wit, the need for variation in the data set so as to allow. for variance-based statistical analyses." Id. This second tendency in particular, according to Lieberson, "is a remarkably deceptive and widespread practice that gums up our ability to. . generate conclusions about what is causing what." Id. This is because data may only be collected about a limited range of potentially "causal" factors, due to the fact that only data about these factors are available in statistically valid, measurable forms. Once the data are gathered and compared, it becomes nearly impossible even for researchers-let alone the ultimate consumers of research findings who are less familiar with what has been excluded-to recall and take appropriate account of the potential causal weight of that which has not been measured.

173. See 2008 Report on Indicators, supra note 152, 99 27-33.

174. See id. ๆ 11. 
On the other hand, the OHCHR's indicator initiative does represent an improvement in inclusiveness concerning sources of data. OHCHR sees both official socio-economic data sources and NGO sources of events-based data as valuable for assessing government efforts and outcomes. ${ }^{175}$ The OHCHR suggests that data from official statistical agencies should be "of primary importance" for treaty bodies, since such data are produced by the State itself through "a standardized methodology." 176 Such data include the familiar socioeconomic data collected by State agencies that is frequently utilized by development professionals. ${ }^{177}$ With respect to "alleged or reported cases of human rights violations," NGO sources are lauded. ${ }^{178}$ Though nowhere stated, the assumption here is that-of course--States will not accurately report on their own abuses, and that NGO accounts must therefore be relied upon as the primary sources for such data, despite their much-criticized lack of uniformity ${ }^{179}$ and alleged subjectivity. ${ }^{180}$ OHCHR deals with this by suggesting that NGO data can be "processed in a standardized manner" by U.N. agencies or national human rights institutions before being used in the indicators framework. ${ }^{181}$

OHCHR also recognizes that indicators should be designed holistically, given the intertwined nature of rights. For example, the framework recognizes that a process indicator for one right may be an outcome indicator for another. ${ }^{182}$ For example, the indicator "Proportion of population using an

175. See id. $\ 13$.

176. See id. I 13 ("The use of a standardized methodology in the collection of information, whether it is through census operations, household surveys or through civil registration systems, and usually with high level of reliability and validity, makes indicators based on such a methodology vital for the efforts to bring about greater transparency, credibility and accountability in human rights monitoring.").

177. A recent article suggests that such familiar data could be the basis for assessing State compliance with the ICRSCR. See Clair Apodaca, Measuring the Progressive Realization of Economic and Social Rights, in ECONOMIC RightS: CONCEPTUAL MEASUREMENT, AND POLICY ISSUES, supra note 99 , at 165,174 (noting that "[t]he indicators are chosen because of their direct connection to the enumerated rights" in the ICESCR).

178. See 2008 Report on Indicators, supra note 152, 14 ("Events-based data consists mainly of data on alleged or reported cases of human rights violations, identified victims and perpetrators. Indicators, such as alleged incidence of arbitrary deprivations of life, enforced or involuntary disappearances, arbitrary detention and torture, are usually reported by NGOs and are or can also be processed in a standardized manner by, for instance, national human rights institutions and special procedures of the United Nations.").

179. For concerns about lack of uniformity, see, for example, LANDMAN, supra note 61, at 88 ("Events-based data are prone to either under-reporting of events that did occur or over-reporting of events that did not occur, creating problems of selection bias and misrepresentative data.").

180. For a discussion of critiques of events-based data, see, for example, TODD LANDMAN, MAP-MAKING AND ANALYSIS OF THE MAIN INTERNATIONAL INITIATIVES ON DEVELOPING INDICATORS ON DEMOCRACY AND GOOD GOVERNANCE (2003), available at http://www.oecd.org/ dataoecd/0/28/20755719.pdf.

181. See 2008 Report on Indicators, supra note 152, \14.

182. See id. โf 24-25. 
improved drinking water source," currently included as a process indicator for the right to life, also appears as an outcome indicator for the right to adequate housing. ${ }^{183}$ In other words, access to an improved drinking source (a process indicator for the right to life) is a cause of improved life expectancy among children under five (an outcome indicator for the right to life), while access to an improved drinking source is itself reasonably assumed to be caused by-at least in part-the "[s]hare of public expenditure on provision and maintenance of sanitation, water supply, electricity and physical connectivity of habitations" (a process indicator for the right to adequate housing). ${ }^{184}$

While the OHCHR states that "qualitative and quantitative indicators are both relevant in the work of treaty bodies," it explicitly designed the framework around the use of quantitative indicators since that is what it was requested to do by the treaty bodies. ${ }^{185}$ The resulting silence on how qualitative indicators can be used is highly problematic, since it creates the impression that qualitative indicators are largely irrelevant when assessing a State's compliance with its human rights obligations. Issues of feasibility have also come center stage: the OHCHR has made efforts "to keep the identified indicators simple, based on standardized methodology for data collection and, to the extent feasible, with an emphasis on disaggregation of information by prohibited grounds of discrimination and by vulnerable or marginalized population groups, who have to be the target for public support in furthering the realization of human rights." 186 Because populations-and discrimination-differ across countries, the framework encourages users to identify the most relevant categories for disaggregation, recognizing that the process of producing disaggregated data is expensive and time consuming. For example, an indicator such as "net primary enrollment ratio by target groups," listed as a process indicator for the right to education, will need to be disaggregated on grounds such as "sex, disability, ethnicity, religion, language, social or regional affiliation of people." 187 Human rights law prohibits discrimination on all of these grounds, meaning that enrollment rates that differ across these categories would be highly relevant in assessing the adequacy of a State's efforts to dismantle discrimination and enhance equality. However, it is often too expensive for national bodies to break down information along all of these axes given competing demands. ${ }^{188}$

183. See id. $\llbracket \llbracket 22,29$.

184. See $i d . \eta 29$.

185. See id. ๆ 4 n.5.

186. See id. $\{44$.

187. See id. ๆ 10.

188. An illustrative anecdote may be helpful here: while on a human rights field visit for a women's rights project, Satterthwaite asked the representative of a national women's ministry why they did not demand that the national statistical office disaggregate basic socio-economic indicators by sex. "They have demanded that we pay for each indicator we want disaggregated by sex," the ministry employee explained. "We simply do not have the resources to pay for this." Sandra Fredman also points to the problem of data collection in the context of resource-poor countries. See Sandra Fredman, Socio-Economic Rights and Positive Duties, in HuMAN Rights TranSFORMED, 
Thus, the internationally-identified indicators will need to be adapted to the national situation, so that national bodies collect and report on those categories of the population most likely to experience discrimination. ${ }^{189}$

Despite these significant advances, the framework set out by the OHCHR reflects a continuing lack of clarity about a number of crucial issues. Perhaps most importantly, the OHCHR does not specify who, in addition to the treaty bodies, should use the indicators it has identified, but instead suggests that they will be useful both for assessing compliance with human rights commitments, and for rights-based monitoring of development projects. ${ }^{190}$ Rights-based monitoring is an activity that is distinct from monitoring States' compliance with human rights treaties. While it necessarily involves a close examination of States' efforts in areas covered by relevant treaties, the goals of each type of monitoring are different. When assessing compliance with a treaty, the assessor is determining the extent to which a State has met its duties under a legal standard. When assessing a development project from a rights-based perspective, the assessor is determining the extent to which the project has advanced human development while also enhancing human rights. Indicators, therefore, are likely to differ significantly based on their use.

With respect to monitoring State compliance with human rights treaties, the OHCHR specifies that "[i]t is the objective of the work undertaken by OHCHR for the treaty bodies to identify relevant quantitative indicators that could be used in undertaking human rights assessments." ${ }^{191}$ Toward this end, the OHCHR concludes that further work is needed to identify a "treaty-specific list of illustrative indicators." 192 Given its determination that indicators also should be context-specific and participatory, the tension between State-specific and universal indicators appears to continue through the OHCHR's indicators project. What role different actors (including the treaty bodies, States, OHCHR, and civil society) will have in selecting and using the various indicators in the monitoring process remains unclear. This is striking, not only since it represents a significant shift from the original task of identifying indicators for use by the treaty bodies, but also since there are enormous differences-legally and politically - among the various potential uses of the indicators forwarded by the OHCHR. For example, the treaty bodies have treaty-bestowed authority since they are charged with monitoring State compliance under the relevant treaty

supra note 43, at 204-40, 215. See also Welling, supra note 3, at 939 (explaining that many developing countries are "ill-equipped to provide necessary disaggregated data"), and Fukuda-Parr et al., supra note 12 , at 8 .

189. The Special Rapporteur on the Right to Health, Paul Hunt explains: "[V]ulnerability and discrimination are contextual. While a group might be especially vulnerable in one context, it might not be in another. Thus, in a particular national context, there might be a case for giving priority to the collection of some disaggregated data rather than others." See 2006 Hunt Report, supra note 154, If 10.

190. See 2008 Report on Indicators, supra note 152, rr 35-36.

191. See id. 35.

192. See id. 7 . 
(though this authority is always contested). Their use of the OHCHR indicators will carry with it a certain weight not present among other users. States have another type of authority - the type drawn on by the CESCR when it has called on States to themselves create indicators. States' adoption of the OHCHR indicators would go some distance toward legitimizing the framework, though it certainly would not have binding effect on other States under the international legal regime. The adoption and use of the OHCHR indicators by NGOs and other advocates would carry with it no special authority, though it would potentially lend the aura of legitimacy otherwise potentially lacking in this exercise.

Finally, whether the indicators being designed actually do measure what they purport to measure is something that will need to be assessed over time. The OHCHR concludes that its current framework:

allows a balance between the use of a core set of human rights indicators that may be universally relevant and at the same time retain[s] the flexibility of a more detailed and focused assessment on certain attributes of the relevant human rights, depending on the requirements of a particular situation. ${ }^{193}$

In other words, the OHCHR appears to hope that a core set of universal indicators can be agreed upon, but suggests that this core set will be complemented by more contextual indicators. In its report, the OHCHR sets out "indicators for 12 human rights and the approach to the selection and contextualization of indicators with a view to encourage the application of the work at country level and in the treaty bodies." 194 However, the OHCHR nowhere states who will adapt the indicators to the national level, or what relationship such choices--if made by actors other than the treaty bodies-will have on how treaty bodies use indicators when assessing State compliance with human rights law. Instead of answering this question, the OHCHR presents the issue as a technical one, explaining that the framework presented "enables the potential users to make an informed choice on the type and level of indicator disaggregation that best reflects their contextual requirements for implementing human rights or just some of the attributes of a right, while recognizing the full scope of obligations on the relevant human right standards." 195 Thus transformed, the issue of authority and judgment-always lurking behind the corner of the human rights regime--is again hidden from sight, buried in language concerning "informed choice[s]" to be made by experts.

In this way, human rights indicators share the attributes of other types of standards. As Bengt Jacobsson has said, "[s]tandardization may be regarded as a way of regulating in a situation where there is no legal centre of authority." Ominously characterizing the brave new "world of standards" that he and his colleagues set out to critically analyze, he continues: "[w]e will have a kind of

193. See id. ๆ 43.

194. Id. ๆ 41 .

195. Id. ๆ 43 
symbolic and secularized society based on the premise that people voluntarily conform to the decisions of authorized expert knowledge. But while order is being established, responsibility may be vanishing."196

Two responsibilities are at risk of vanishing in the context of human rights indicators: first, the responsibility for transforming into measurable indicators the more or less fully articulated normative standards that derive from international human rights treaties and the treaty bodies' interpretations of them; and second, the choice of indicators that will be used to measure human rights commitments. The work of experts who designed these standards at the request of the treaty bodies effectively disappears when one is confronted with the final product: a neat set of one-page matrices that set out structural, process, and outcome indicators for the major human rights delineated in international human rights treaty law. Jacobsson points to three significant problems "related to standardization, which stem from reliance on experts: depoliticization, technicalization, and the emergence of regulation without responsibility."197

Technicalization is present in the case of human rights indicators, where expert knowledge is packaged into lists of illustrative indicators and their accompanying explanatory "meta-sheets," which are forwarded as useful for all involved-States being monitored, individuals whose rights need protection, and treaty bodies who have only contested authority. Seeking voluntary use of these indicators by "human rights stakeholders," including "human rights, development and statistical practitioners," 198 the OHCHR champions the technical superiority of its conceptual framework and its adaptability to national context. Further, it does so using the language of professional expertise. ${ }^{199}$ As Jacobsson explains, "Standards make organizations visible and possible to control and audit. When standards are assumed to embody what the experts have found to be best- that is, treated as technical in nature-it may be held that this control is objective and non-controversial."200

Why is this a problem? Bengt Jacobsson ${ }^{201}$ and Sally Engle Merry ${ }^{202}$ argue that the danger lies in the potential for standards to depoliticize choices

196. Bengt Jacobsson, Standardization and Expert Knowledge, in A WORLD OF STANDARDS 40 (Nils Brunsson et al. eds., 2000). This edited collection traces standardization practices through a diverse array of overlapping geographical and institutional contexts-private, national, local, interand non-governmental. David Kennedy makes a similar point about the role of experts and expertise in international legal arenas. See Kennedy, supra note 5.

197. Jacobsson, supra note 196, at 49.

198. 2008 Report on Indicators, supra note 152, $\{33$.

199. For example, OHCHR explains that the "expert group peer reviewed all proposals made by the secretariat on the concept, methodology, the choice of illustrative indicators, as well as the process for validating the results at country level," thus relying on the validation of such peer review as legitimizing its choices. Id. $\ 27$.

200. Jacobsson, supra note 196 , at 45 .

201. Id.

202. Merry, supra note 5, at 21. 
that would otherwise be openly contested in the public sphere. Here, the marketing by OHCHR of its indicators seems intended to bring States voluntarily into closer line by persuading those with whom they work-"human rights stakeholders"- that indicators offer a technical answer to what would otherwise appear to be judgment-laden (and thus court-like) or highly contested (and thus political) issues. The auditing role of the CESCR is thereby maintained, but now with States being asked to use the rules set out by international experts rather than those of the State's choosing. ${ }^{203}$ In this way, what might otherwise appear as a bold assertion of authority and power by the treaty bodies is passed off as a technical exercise that should be voluntarily accepted by rational human rights practitioners-including those working for the State.

In the end, however, this effort will never solve the problem that generated the CESCR's audit practice to begin with: the relationship of distrust between the treaty bodies and the States whose efforts they monitor. This is because, although it appears to do so, the framework forwarded by the OHCHR will never be able to do the real work of assessing where States have fallen short of their obligations under human rights treaties. To take one example: while the framework created by the OHCHR identifies interconnections between rights (recall the example of "Proportion of population using an improved drinking water source" used as a process indicator for one right and an outcome indicator for another), it does not do what will be needed to actually assess compliance with interlocking human rights obligations in real-life situations. Further, how will the user of the indicators framework determine whether the choices that a State has made--to engage in a specific effort that could be measured by a process or outcome indicator-is what is needed in the given context to ensure compliance with the standard set out in the treaty? While the conceptual clarity concerning the standard of progressive realization is helpful, even a pristine level of clarity will never allow a human rights professional to assess as a technical matter the adequacy of the State's measures because adequacy is never only a technical question. To use another example, imagine an assessor seeks to

203. Theorists of "governmentality" would surely read this-with some good reason-as a profoundly Althusserian/Foucaultian move in that the OHCHR and treaty bodies seem to be interpellating States in ways analogous to those States have been described as using to interpellate their citizen-subjects. See Louis Althusser, Ideology and Ideological State Apparatuses, excerpted in CRITICAL THEORY SINCE 1965245 (Hazard Adams \& Leroy Searle eds., 1971). Althusser uses the term interpellation to describe the processes by which apparatuses of the state, via ideology, ensure we will recognize ourselves as subject to its rule. His famous example is of a citizen who, upon hearing a police officer shout "Hey, you?" is moved almost involuntarily to turn in response, recognizing that the officer may be calling him, and in so doing, recognizing that officer's authority to "hail" him. Foucault describes the complex processes of "subjectification"-by which individuals come to inhabit positions within the structure of language-in a much more thorough-going manner through several books. See, e.g., Michel FouCAULT, DisCIPLINE AND PUNISH: THE BIRTH OF THE Prison (1977); Michel Foucault, The History of SEXuality: An InTRoduction, Vol. 1 (1978). A good summary can be found in Nick Mansfield, SUBJECTIVITY: THEORIES OF THE SELF FROM FREUD TO HARAWAY (2000). We will touch briefly upon this literature infra in Section V. 
determine the adequacy of a State's allocations to primary education and to the promotion of higher education for women. Imagine further that the State in question has an extensive primary school system, but that it has systematically undervalued women's roles in the professions. How will the user of the indicator "share of public expenditure on education devoted to primary education" know whether a State's choice to allocate proportionally less money to primary education than it allocates to scholarships and professional training for women is permissible when simultaneously confronted with the indicator "proportion of females with professional or university qualification"? 204

Such can never be a technocratic assessment. It requires, instead, the exercise of judgment. By evading possibly the most thorny issue-who will be the final arbiter of which indicators will be used, and how exactly they will be used to assess State compliance with international human rights law-the OHCHR evades one of the most difficult issues in human rights law: that of authority. In the end, the discussion of human rights indicators requires us to attend to the issue of judgment, and the unique challenges posed by a system of law that fails to locate authority for judgment in any given body. Implicitly recognizing this problem but seeking to elide it, the OHCHR deploys the language of expertise. While its framework for human rights indicators is conceptually clear and may allow for powerful advocacy, it does not resolve the underlying problem that its apparent trust in numbers seeks to fix-the pesky, irreducible core of human judgment.

$\mathrm{V}$.

\section{HUMAN RIGHTS INDICATORS AS TECHNOLOGIES OF GLOBAL GOVERNANCE}

In many ways, the turn to indicators in the human rights context mirrors trends across the landscape of transnational governance. These trends, manifested in part by audit practices like those discussed in Section II and receiving attention from science and technology studies scholars, are also coming under critique from across the disciplines under the rubric of "global governance" and "governmentality" analyses. Particularly in the fields of anthropology, critical development studies and political science, scholars have produced a large body of literature examining the globalizing spread of regulatory regimes that involve statistical reporting requirements and the imposition of universal standards. ${ }^{205}$ The gist of these critiques is well-

204. Both of these indicators are included as illustrative of the right to education. See 2008 Report on Indicators, supra note 152, at 28. Kate Raworth has also noted the failure of human rights indicators projects to assess the trade-offs that States often make among competing rights. See Raworth, supra note 98, at 399.

205. See, e.g., ANNA LOWENHAUPT TSING, FRICTION: AN ETHNOGRAPHY OF GLOBAL CONNECTION (2004); GLCBAL AsSEMBlages: TECHNOLOGY, POLITICS, AND ETHICS AS ANTHRopological PROBlems (Aihwa Ong \& Steven J. Collier eds., 2004); ANTHRopologiEs of MODERNITY: FOUCAULT, GOVERNMENTALITY, AND LIFE POLITICS (Jonathan Xavier Inda ed., 2005); 
summarized by Bengt Jacobsson, who warns that:

Greater reliance on standards may involve a danger that so-called technical expert knowledge will become a substitute for ethical and political discourse. . . . There will be a growing focus on how things are done-a focus on form rather than content. ${ }^{206}$

The move to audit by the CESCR, through which the treaty body has used indicators to shift its focus from monitoring the compliance of States with States' treaty obligations to a monitoring of States' own monitoring activities, may in part embody this shift from content to form. Further, it risks displacing contestation over substantive rights issues onto seemingly bureaucratic or technical decisions about choice of indicators. In her recently initiated ethnographic project to study rights indicators, Sally Engle Merry lodges a similar critique:

[T] he creation and use of indicators often means disappearing politics into the technical. It means creating administrative mechanisms that to varying degrees obscure their political origins and agendas. ${ }^{207}$

This is the promise and peril of numbers. As Merry points out:

Numbers are the epitome of the modern fact because they seem to be simple descriptors of phenomena and to resist the biases of conjecture and theory since they are subject to the invariable rules of mathematics. Numbers have become the bedrock of systematic knowledge because they seem free of interpretation, as neutral and descriptive. They are presented as objective, with an interpretive narrative attached to them by which they are given meaning. ${ }^{208}$

As the treaty bodies have turned to the OHCHR for assistance with the development of universal human rights indicators, thereby extending the turn to expert assistance, it would seem that this danger has, if anything, increased. Scholars who study globalization practices have noted the many ways in which the turn to technocratic numeracy can result in bureaucratic stalemates at best

ANTHRopology and Policy: Critical Perspectives on Governance and Power (Cris Shore \& Susan Wright eds., 1997); THE ANTHROPOLOGY OF DEVElopMENT AND Globalization: From Classical POlitical ECONOMY to CONTEMPORARY NEOliberalism (Marc Edelman \& Angelique Haugenud eds., 2005); THE ANTHROPOLOGY OF GLOBALIZATION: A READER (Jonathan Xavier Inda \& Renato Rosaldo eds., 2007); JOHN Boli \& GEORGE M. THOMAS, CONSTRUCTING WORLD CULTURE: INTERNATIONAL NONGOVERNMENTAL ORGANIZATIONS SINCE 1875 (1999); CONTESTING Global Governance: Multilateral ECONOMIC InStitutions and Global SOCIAL MOVEMENTS (Robert O' Brien et al. eds., 2000); James FERGUSON, EXPECTATIONS OF MODERNITY: MYTHS AND MEANINGS OF URBAN LIFE IN THE ZAMBIAN COPPERBELT (1999); Globalization UNDER CONSTRUCTION: GOVERNMENTALITY, LAW, AND IDENTITY (Richard Warten Perty \& Bill Maurer eds., 2003); DAVID Held, DEMOCRACY AND tHE GlOBAL ORDER: From the MODERN STATE TO COSMOPOLITAN GOVERNANCE (1995); JAMES C. SCOTT, SEeING LIKE A STATE: How CERTAIN SCHEMES TO IMPROVE THE HuMAN CONDITION HAVE FaILED (1998); Transnationalism From Below (Michael Peter Smith \& Luis Eduardo Guarnizo eds., 1998).

206. Jacobsson, supra note 196, at 46.

207. Merry, supra note 5, at 21 .

208. Id at 26 (citing MARY POOVEY, A History OF THE MODERN Fact: Problems of KNOWLEDGE IN THE SCIENCES OF WEALTH AND SOCIETY (1998)). 
and a range of negative unintended consequences at worst. ${ }^{209}$

One of the unintended consequences may be the tendency of compliance indicators to close down spaces for democratic contestation. In carrying out their human rights obligations, States must continually make difficult prioritization choices, especially in the context of economic and social rights. Which rights should receive the State's most concentrated attention-the right to potable drinking water or the ability to access childhood vaccinations? Gender equality in higher education or ensuring non-discriminatory employment conditions? How should government authorities make such determinations? Who should decide and by what means? And most relevant to our purposes, what does human rights law have to say about these challenging questions, and how might indicators measure States' efforts to answer them?

In many respects, human rights law has very little to say of a concrete nature. Prioritization challenges are often answered with the demand that all rights receive equal attention and priority-a claim often made by those invoking the principle of indivisibility. ${ }^{210}$ In practice this is seldom, if ever, possible at the level of everyday policy-especially in resource-poor countries. Moreover, this principle does not mean very much in practice, since governments formulating policy are continually forced to stress some policies or actions over others. However, while there may not be clear answers to the question of prioritization, a good deal of work has been done to establish more concrete standards to guide and cabin governments' choices concerning competing rights demands. The concept of minimum core obligations, discussed earlier in this Article, requires that States act to immediately fulfill certain basic rights standards, regardless of the economic status of the country, thus forcing prioritization of actions to achieve those goals. ${ }^{211}$ The principles of non-discrimination and equality have been interpreted to impose duties on States to ensure that they immediately prioritize the rights of the most vulnerable and marginalized communities. ${ }^{212}$ Moreover, the principle of non-retrogression

209. See, e.g., Shore and Wright, supra note 205, at 4-39. Richard Harper, The Social Organization of the IMF's Mission Work: An Examination of International Auditing, in AUDIT CULTURES: ANTHROPOLOGICAL STUDIES IN ACCOUNTABILITY, ETHICS AND THE ACADEMY 21-54 (Marilyn Strathern ed., 2000).

210. See, e.g. Vienna Declaration, supra note 19, at If 5 ("All human rights are universal, indivisible and interdependent and interrelated. The international community must treat human rights globally in a fair and equal manner, on the same footing, and with the same emphasis."). See also U.N. Development Group, The Human Rights Based Approach to Development Cooperation: Towards a Common Understanding Among U.N. Agencies, available at www.unicef.org/sowc04 /files/AnnexB.pdf (last visited Oct. 23, 2008). This Common Understanding is used by all U.N. agencies in their development programming. See id.

211. States that are unable to fulfill the minimum core obligations are required to "demonstrate that every effort has been made to use all resources that are at its disposition in an effort to satisfy, as a matter of priority, those minimum obligations." CESCR, General Comment No. 3, supra note 41, I 10.

212. See, e.g. Vienna Declaration, supra note 19, at If 24 ("Great importance must be given to the promotion and protection of the human rights of persons belonging to groups which have been 
means that governments must ensure that their policies and actions are designed to ensure that rights fulfillment is not diminished, but instead progresses forward toward full enjoyment. ${ }^{213}$

These principles provide a good deal of guidance to States seeking to uphold their human rights obligations, and in some scenarios, States may rely upon them to prioritize activities. However, the principles will often fail to provide the answers to questions about prioritization and emphasis in implementation. They will only rarely provide a rule of decision for policymakers choosing among options for actions that can improve human rights. This gap-between international norm and domestic implementation-is both normal and desirable. It opens space for States-and more importantly, for national populations within States--to determine how best to carry out their duties. $^{214}$ Within this space, democratic contestation and participation by those most directly affected can take place. ${ }^{215}$ Without such a gap, human rights law

rendered vulnerable, including migrant workers, the elimination of all forms of discrimination against them, and the strengthening and more effective implementation of existing human rights instruments.").

213. See, e.g., CESCR, General Comment No. 3, supra note 41, f 9. States may derogate from the principle of retrogression in circumstances where this becomes necessary, but the CESCR has noted that "any deliberately retrogressive measures in that regard would require the most careful consideration and would need to be fully justified by reference to the totality of the rights provided for in the Covenant and in the context of the full use of the maximum available resources."

214. The Inter-American Commission on Human Rights cogently explains the situation this way when explaining the function of indicators for monitoring progress with the San Salvador Protocol on economic and social rights:

It is as well to recall at the outset that the monitoring procedure provided in the Protocol is not intended to assess the quality of the public policies of states, but to monitor compliance or otherwise with their legal obligations under the Protocol. The Protocol contains an extensive range of obligations, both positive and negative, as well as immediate and progressive. In order to oversee compliance with these obligations it will frequently be necessary to observe which strategies, measures, and public policies states have implemented in an attempt to ensure the exercise of rights. Clearly, states can meet their obligations by choosing from a broad range of courses of action and policies. It is not for international monitoring and mechanisms to judge those options that each State has selected in exercise of its sovereignty to realize the rights contained in the treaty. It will be necessary, however, to determine if those public policies violate rights recognized in the Protocol, and to examine whether or not they have managed, through those policies, to fulfill of their positive obligations whether immediate or progressive- under the Protocol. The ultimate aim of the system of indicators and signs of progress is not, then, to review policy, but only examine policies, aspects thereof, or the impact of certain policies, as a means to arrive at certain conclusions regarding extent of compliance with and implementation of the Protocol.

Inter-American Commission on Human Rights, Guidelines for Preparation of Progress Indicators in the Area of Economic, Social, and Cultural Rights (2008), §1, ๆ 4.

215. This space is similar to that which some scholars have sought to protect in remedial orders following supranational litigation of economic and social rights. See, e.g., Tara Melish, Rethinking the 'Less as More' Thesis: Supranational Litigation on Economic, Social and Cultural Rights in the Americas, 38 N.Y.U. J. INT'L L. \& POL. 171, 340 (2006) (calling on advocates to seek remedial orders from supranational institutions that "create[] the interstices necessary for civil society to 
would perversely short-cut democratic processes by imposing specific policy choices on States. ${ }^{216}$

Indicators may threaten to close the fruitful gap between international law and domestic policy by, for example, measuring the outcomes of certain policies, or even turning specific policy choices themselves into indicators. ${ }^{217}$ For an example of the latter, the indicator "coverage of targeted population covered under public programs on nutrition education and awareness" has been identified by the U.N. Office of the High Commissioner for Human Rights as an indicator for the right to food. ${ }^{218}$ While such programs are one way to achieve an important element of the right to food, they might not be the one preferred by the inhabitants of a specific State, who may want funds to be spent on direct food aid, or supplements to farmers who cultivate staple foods. Further, given the problems of measurability and availability of data discussed earlier, there may be a tendency to choose indicators that capture the outcomes of the most easily - or the most consistently-measurable policies or programs. For example, "proportion of targeted population covered under public nutrition supplement programs" has been used by OHCHR as an indicator for the right to food. This indicator asks the government to count something it is very likely already counting - the number of households benefitting from its own ("public") nutrition supplement programs. This indicator may reveal a great deal in countries that have chosen to respond to hunger and malnutrition with State-run supplement programs. It will be less revealing of the extent to which the right to food is being fulfilled in countries where the non-profit sector has taken on greater food supplementation duties than the State, however. Because of the bias in indicator construction toward choosing easily countable phenomena, one kind of indicator is more likely to be chosen than another. Finally, indicators that measure the outcome of only certain specific policies, and indicators that mandate specific policy choices, have an attenuated relationship to the legal norm at issue. They are therefore ill-suited for use in monitoring compliance with legal duties.

In sum, the development and use of compliance indicators may have the tendency to artificially close the gap between international law and domestic policy, thus shrinking the required spaces for participation. If they are designed and imposed uniformly across countries, and if they are not capable of calibration according to national priorities and deliberation, indicators could

remain actively involved in continually pressing the government to comply with its human rights obligations.").

216. As Sandra Fredman explains, this gap does not detract from the determinacy of the norm: "Nor is it necessary to specify precise steps to be taken for a duty to be determinate. This would preclude any autonomous input from domestic decision-makers, giving no space for the distribution of decision-making required by the principle of institutional competence." Fredman, supra note 43, at 77 .

217. Welling notes this danger as well. See Welling, supra note 3, at 956-57.

218. OHCHR, 2008 Report on Indicators, supra note 152, at 25. 
backfire as an accountability mechanism. By cutting out spaces for democratic accountability, they could become a technical means of measuring domestic policy against overly rigid internationally-imposed rules.

So it would seem that there is little to applaud in this latest manifestation of the "turn to indicators"- however tentative and "illustrative," however strewn with caveats they might be-by the OHCHR. And yet, as we have traced the human rights treaty bodies' ongoing efforts to grapple with the task of holding States accountable for their commitments to human rights treaties, we have come to appreciate new aspects of this project that a "governmentality"-focused analysis risks occluding.

What we are calling a "governmentality-focused analysis" might focus solely on the dangers inherent in the turn to indicators-on the evasion of difficult questions of judgment represented by the human rights community's embrace of technocratic numeracy, and on the concomitant submersion of political debates "by technical questions of measurement, criteria, and data accessibility."219 Such an analysis is offered in another context by Suzan Ilcan and Lynne Phillips in their examination of the U.N. Food and Agriculture Organization (FAO). They describe the FAO as one among many U.N. agencies making up a "'bureaucratic machinery' that has assembled various technologies of government [reliant] upon a variety of specialized knowledges and practices of evaluation to govern food and agriculture, education and science, and world health issues." 220 In their reading, the FAO's use of "statistical expert knowledge" constitutes one among many "global technologies of government"221 now "produc[ing] the need for so-called less developed

219. Merry, supra note 5, at 16 ("In sum, the expansion of the use of indicators in global governance means that political struggles over what human rights mean and what constitutes compliance are submerged by technical questions of measurement, criteria, and data accessibility. Political debates about compliance shift to arguments about how to form an indicator, what should be measured, and what each measurement should represent. These debates typically rely on experts in the field of measurement and statistics, usually in consultation with experts in the substantive topic and in the national and international terrain. They rely on previous research studies and knowledge generated by scholars. The outcomes appear as forms of knowledge, rather than as particular representations of a methodology and particular political decision about what to measure and what to call it. An indicator provides a transition from ambiguity to certainty, theory to fact, complex variation and context to truthful, comparable numbers. In other words, the political process of judging and evaluating is transformed into a technical issue of measurement and counting by the diligent work of experts.").

220. Suzan Ilcan \& Lynne Phillips, Making Food Count: Expert Knowledge and Global Technologies of Government, 40 CANADIAN REV. SOC. \& ANTHROPOLOGY 441, 445-46 (2003) (internal citations omitted).

221. Id. at 442; see also NikOLAS ROSE, POWERS OF FREEDOM: REFRAMING POLITICAL THOUGHT 52 (1999) ("A technology of government, then, is an assemblage of forms of practical knowledge, with modes of perception, practices of calculation, vocabularies, types of authority, forms of judgment, architectural forms, human capacities, non-human objects and devices, inscription techniques and so forth, traversed and transected by aspirations to achieve certain outcomes in terms of the conduct of the governed.") (internal citations omitted). We extend this term to elaborate what we refer to as global technologies of government, namely, the dispersion of a 
countries to change their ways. Professional forms of expert knowledge, such as those based on scientific classification and calculation, were essential in shaping and steering social and economic conduct on a global scale."222

It would be easy enough to apply a similar analysis to the work of treaty bodies and the OHCHR in developing international human rights indicators. Surely this project too could be termed a "global technolog[y] of government." Certainly the turn to experts for putatively independent, bias-free, and scientifically valid techniques with which to assess the degree to which States are living up to the commitments they make represents the OHCHR's participation in wider transnational governance trends. Additionally, the fact that OHCHR is part of the United Nations and, as such, is one among many intergovernmental agencies that seek to change policies in rationalized ways, clearly makes it a player in the spread of twenty-first century methods of neoliberal governance. As Ilcan and Phillips explain,

[w] ithin the governmentality literature, government is understood as a calculated and rationalized activity undertaken by multiple authorities and agencies employing various kinds of techniques and knowledge designed to shape conduct. In other words, government operates through the capacities of those who govern, including those international agencies like the United Nations. These agencies transform the terrain of government policies and national populations by promoting their engagement with, among other things: acceptable living standards; modern legislative systems; enumeration practices; particular models of development; and statistical accounts of human and nonhuman capacities. ${ }^{223}$

Through human rights indicators, the CESCR and OHCHR are certainly "promoting" the "engagement with" various international standards in order to shape the conduct of governments-that is, they are intending to "transform the terrain of government policies." However, there are significant differences that should be noted as well. Much of the governmentality literature, while helpfully diversifying our conceptions of those who govern, ${ }^{224}$ nonetheless often implicitly assumes-through its choice of examples-that the targets of governance are largely, if not solely, citizens and populations. ${ }^{225}$ Human rights

wide range of techniques (e.g., numerical, classificatory, spatial, visual and discursive) that work beyond the nation-state to govern conduct.

222. Ilcan \& Phillips, supra note 220 , at 442 (emphasis added).

223. Id. at 444 (internal citations omitted).

224. See Andrew Batry, Ethical Capitalism, in Global Governmentality: Governing INTERNATIONAL SPACES 195, 202 (Wendy Lamer \& William Walters eds., 2004) ("Writers on governmentality, following Foucault, have long emphasized that the activity of government cannot be reduced to the actions of the state. In an era where direct state control and ownership has declined (because of privatization and re-regulation), or is difficult (because of the transnational organization of companies), international institutions, NGOs, auditors, consultants and multinational corporations are together expected to perform the job of government at a distance. Global governmentality has been associated with the dispersion of governmental functions amongst a network of international and non-state institutions. Within this network, clear distinctions between the identities and functions of different institutions may sometimes be difficult to make.").

225. The term "governmentality" originates in a series of lectures given by Michel Foucault in 1978 , as part of two courses on "the problematic of bio-power." MICHEL FOUCAULT, SECURTT, 
indicators, on the other hand, emerge out of projects aimed at changing the conduct of governments toward those same populations. We believe that this difference matters - that the power of quantitative indicators, when harnessed by human rights advocates, may be fruitfully turned on the State by those the State has harmed. Indeed, we believe that human rights indicators-if designed with these valences of power in mind - can be used to monitor whether governments have arrived at effective human rights policies and actions through democratic processes. In other words, instead of disappearing politics, indicators should be designed to allow for the monitoring of governmental processes to ensure they are participatory and open to deliberation and debate.

Safeguarding the necessary gap between norms and their implementation does not preclude monitoring States' duties using indicators, but it does mean that monitoring will always be context-dependent, that it will involve the function of judgment, and that it will never be a purely technical exercise. In part because States distrust the treaty bodies and thus often do not accept the judgment of those bodies in the monitoring context, human rights indicators have been especially attractive since they appear to transform monitoring from a

TERRITORY, POPULATION: LECTURES AT THE COLLĖGE DE FRANCE 1977-1978 (Michel Senellart ed., 2007) [hereinafter SECURITY, TERRITORY, POPULATION]. The term originates in Foucault's studies of the formation of the modern State and its multiplying techniques for exercising power over populations. In his account of the transition from sovereign rule to modern liberal State power, Foucault suggests that the "two great assemblages of political knowledge and technology" were: first, a combination of national military forces and diplomacy that permitted "equilibrium" external to, and between (European) nation-states; and second, a host of consolidating forces internal to the state, particularly commercial and monetary forms. Id. at 365 . Together, all worked "to affirm and increase the power of the state," and served to maintain "order and discipline, the regulations that tend to make [the lives of the States' subjects] convenient and provide them with the things they need to live." Id. at 366 . And according to historians like Porter, these State powers were inextricably intertwined with population demographics. See PORTER, supra note 1, at 37; see also THEODORE PORTER, THE RISE OF STATISTICAL THINKING: 1820-1900, 156-57 (1988). The very category "society" upon which the reason for the existence of the State rested was "largely a statistical construct":

The regularities revealed in suicide and crime could not be attributed to individuals. A broader category was needed to account for them, and beginning around 1830, they were designated properties of society. Such regularities were powerful evidence of the autonomous existence of society, of "collective forces," as Durkheim famously argued.

Wendy Nelson Espeland \& Mitchell L. Stevens, Commensuration as a Social Process, 24 ANN. REV. SoC. 313, 325 (1998) (internal citations omitted).

While Foucault went on, in his studies of sexuality in particular, to study the ways that sovereign power is dispersed at micro-levels and exercised at daily, individual levels, "the center of gravity of the lectures" is definitively on the state and its governing of populations." Michel Senellart, Course Context, in SECURITY, TERRITORY, POPULATION, supra at 370 . Thus, the human rights community's efforts to use statistics as part of a larger project of holding governments accountable to their populations, while it partakes of the same technologies of governmentality, can arguably be said to aim at different ends. Rosga describes a similar phenomenon as "using the state against itself" in her ethnographic account of anti-hate crime activists who strategically employed the legal category "hate crime" in contexts where they knew it to carry inherent risks of troubling new legal precedents. See AnnJanette Rosga, Policing the State, 1 GEO. J. GENDER \& L. 145, 166 (1999). 
process laden with judgment into a technical exercise. For the reasons discussed earlier, however, if indicators are created at a level of specificity that would allow the treaty bodies to determine compliance as a technical matter, those indicators would be overly specific, collapsing the very space for democratic participation and accountability that is required by human rights law. Indeed, the human rights framework includes a democratic imperative, often discussed as the right to participation, or the principle of participation and inclusion. ${ }^{226}$ This principle requires "active, free and meaningful participation" in decisions about issues that impact human rights. ${ }^{227}$ Under the rubric of participation, the CESCR has called on States to ensure, for example, that national plans for the achievement of rights be developed through processes that ensure civil society input and deliberation. ${ }^{228}$

The best way to create indicators that respond to the critiques set out in this paper may lie in taking the best of the CESCR's approach to monitoring of monitoring, and the OHCHR's hopes of creating universal indicators, and creating a framework that will have elements of each. Specifically, we recommend that the conceptual framework set out by Paul Hunt and adopted by the OHCHR, in which structural, process, and outcome indicators are created, be retained. $^{229}$ We then suggest that the treaty bodies select-in consultation with the OHCHR and NGOs-a set of outcome indicators that can accurately measure the enjoyment of rights set out in the various treaties if disaggregated appropriately and adjusted over time and context. These indicators could be applied universally. 230

Rather than tasking the OHCHR or the treaty bodies with determining which structural and process indicators should be used in conjunction with these outcome indicators, however, this responsibility should devolve to States, which would use the illustrative indicators as a guide to be supplemented as needed. With respect to structural indicators, States should choose or design indicators

226. See id.

227. Id.

228. See, e.g., ECOSOC, CESCR, Consideration of Reports Submitted by States Parties Under Articles 16 and 17 of the Covenant, Concluding Observations of the Committee on Economic, Social and Cultural Rights, Jordan, \25, U.N. Doc. E/C.12/1/Add.46 (Sept. 1, 2000).

229. The Inter-American Commission on Human Rights has also adopted this framework, supplementing it with "three conceptual categories (incorporation of the right, state capabilities, and financial context and budgetary commitment)," which function like the OHCHR's "attributes" in that each type of indicators-structural, process, and outcome-are further disaggregated into indicators that demonstrate incorporation of the right, State capabilities concerning the right, and the financial context and budgetary commitments concerning the right. Qualitative "signs of progress" are also proposed. See Inter-American Commission on Human Rights, supra note 214.

230. The methodology set out by Fukuda-Parr et al. is promising since it measures the outcome of policies aimed at fulfilling rights, explicitly eschewing the measurement of policies themselves. See Fukuda-Parr et al., supra note 12, at 9 ("assessing policy choice is both difficult and fundamentally inappropriate since 'one size fits all' policy prescriptions are not effective. Appropriate policies to promote ESR fulfillment vary depending on the challenges and constraints within each country."). 
that are capable of measuring the effectiveness of the specific institutions charged with monitoring and enforcing human rights in the given country. For example, if a State has used legal incorporation as a strategy to implement human rights, structural indicators would be designed to examine the relief granted to litigants pressing human rights claims. If States have instead chosen to use national human rights ombudsmen, indicators would measure the ability of those seeking help from the ombudsman to obtain remedies. With respect to process indicators, States should create indicators tailored to assessing the impact of the specific policies it has implemented that are meant to fulfill the rights being examined.

In addition to this process-and perhaps most importantly for this discussion-indicators must be created that will measure the participation of the populace in decisions affecting both institutional design and policy priorities in the field of human rights. Such indicators would capture, for example, the extent to which the population was consulted in the creation of national human rights priorities or plans of action, whether the population is aware of its rights and how to vindicate them, and whether the populace can influence policy changes or even structural decisions impacting human rights. The OHCHR has dealt with the issue of participation by identifying it as a crosscutting issue that should be addressed through choice of indicators. 231 More concretely, the work of the Inter-American Commission on Human Rights sets a helpful example by creating indicators for the cross-cutting issues themselves. In its 2007 Guidelines for Preparation of Progress Indicators in the Area of Economic, Social, and Cultural Rights, the Commission comments on the importance of participation in human rights progress as follows:

One successful strategy to improve the adequacy and pertinence of social policies and services and, therefore, the progressive realization of social rights, is to guarantee a say in the design and implementation of government strategies for civil society organizations, nongovernmental organizations with technical resources and expertise, and groups that represent the sectors targeted by the policies and services. Participatory rulemaking mechanisms, public hearings, consultative councils, and participatory social budgets are ways that have been tried by several countries in the Americas to channel that participation. Another practice considered appropriate for improving transparency and accountability is to increase forums for social participation in evaluation, oversight, and responsibility mechanisms. This document suggests a number of indicators and signs of progress to measure the level or degree of social participation in these processes. ${ }^{232}$

While both the OHCHR and the Inter-American Commission stress the importance of participation - and of monitoring participation generally-we believe this participation should also extend to the process of designing and

231. See 2008 Report on Indicators, supra note 152, at 7-8. Of course, the right to participate in public affairs is also a right on its own, and the OHCHR has created illustrative indicators for that right as well. Id. at 27.

232. See Inter-American Commission on Human Rights, supra note 214, at 82. 
implementing indicators themselves. ${ }^{233}$ Methods that draw on the experience and assessments of the people most directly affected by specific rights concerns could be designed to elicit multiple layers of information about the lived experience of rights set out in international standards. In an assessment of a large-scale project in which the Philippine Human Rights Information Center worked to create a set of ESC standards and indicators, Ramon Casiple concluded that such a "bottom-up approach" to the task was immensely helpful. As a result of an intensively participatory process of developing indicators and standards with the people whose enjoyment of rights were immediately under review, Casiple noted that this "bottom-up approach"

led to the realization that the definition of specific economic, social and cultural rights and their corresponding standards and indicators are subject to evolution and particularities of situations. This speaks of a dynamic process of human rights standard-setting and the need for regular monitoring. It also points to the enormous efforts required to particularize human rights and apply them to varied situations in every country and locality or sector. ${ }^{234}$

Discussions of indicators need not be technical conversations devoid of political contestation. Rosga's ethnographic work suggests that the social actors involved in projects to create indicators are well aware of both the powers and the risks of invoking the fetishistic magic of numbers. ${ }^{235}$ Such conversations do not need to be technocratic and drained of political content; nor must they be conversations in which participants are seeking to submerge difficult questions of judgment in the abstract language of numbers. They should be conversations in which engaged social actors are grappling with the very phenomena we have

233. In this way, consideration of efforts to construct indicators may be enriched through the concept of Global Administrative Law, as formulated by Kingsbury, Krisch, and Stewart. Their focus is on "the mechanisms, principles, practices, and supporting social understandings that promote or otherwise affect the accountability of global administrative bodies, in particular by ensuring they meet adequate standards of transparency, participation, reasoned decision, and legality, and by providing effective review of the rules and decisions they make." As "global administrative bodies," both the OHCHR and the treaty bodies should ensure their decision-making processes are in line with these newly-identified global administrative law principles. See Benedict Kingsbury, Nico Krisch \& Richard B. Stewart, The Emergence of Global Administrative Law, 68 LAW \& CONTEMP. PROBS. 15, 17 (2005). Fredman and Young also recommend that human rights indicators projects be part of a participatory process. See Fredman, supra note 43, at 83; and Young, supra note 63, at 165-66.

234. Ramon Casiple, Emerging Framework and Approaches in Determining ESC Rights' Standards and Indicators: Philippine Grassroots Experience, Montreux (2000), at 4, available at http://www.portal-stat.admin.ch/iaos2000/casiple_final_paper.doc).

235. For a discussion of the fetish of numbers, see Jean Comaroff \& John L. Comaroff, Figuring Crime: Quantifacts and the Production of the Un/Real, 18 PUB. CULTURE 209, 211 (2006) ("[Q]uantifacts - statistical representations that make the world 'factual' — [are] at once ... fetish and the object of a lively hermeneutic of suspicion. . [C]ounter to the commonplace that numbers displace visceral experience into the realm of pattern and probability. . it is arguable that they do just the opposite. . . As they circulate and are mediated,. . . statistics reduce a mass of faceless incidents, disturbing things that happened elsewhere, into the objects of first-person affect: fascination, revulsion, pain."); see also Goldstein, supra note 45, at 50 ("quantitative fetishism" in human rights) 
been describing-actors who are fully aware of both the power and the limits that statistics possess. ${ }^{236}$

VI.

\section{CONCLUSION}

The value of indicators as a social technology cannot be determined in advance, nor on the basis of the fact that they are largely quantitative. While it may be true that quantitative methods, in their very abstraction and stripping away of contextualizing information have particular-and especially highrisks for misuse by those with the power to mobilize them, they are tools like any other. All tools can be misused; all social actors with power can misuse that power. The key lies in knowing where-and how-human judgment and political contestation should enter. Rather than trusting in numbers alone, those using human rights compliance indicators should embrace the opportunities presented by this new project, finding ways to utilize human rights indicators as a tool of global governance that allows the governed to form strategic political alliances with global bodies in the task of holding their governors to account.

236. Since this paper has focused on "official" efforts to create compliance indicators in the human rights context, it has not examined the many-and proliferating-efforts led by NGOs to create and use human rights indicators as advocacy tools. Those efforts will be the subject of a future project by Satterthwaite. 